\title{
The Role of Inspiration in Scientific Scholarship and Discovery: Views of Theistic Scientists
}

\author{
Kari Ann O'Grady \\ Brigham Young University - Provo
}

Follow this and additional works at: https://scholarsarchive.byu.edu/etd

Part of the Counseling Psychology Commons, and the Special Education and Teaching Commons

\section{BYU ScholarsArchive Citation}

O'Grady, Kari Ann, "The Role of Inspiration in Scientific Scholarship and Discovery: Views of Theistic Scientists" (2007). Theses and Dissertations. 1268.

https://scholarsarchive.byu.edu/etd/1268

This Dissertation is brought to you for free and open access by BYU ScholarsArchive. It has been accepted for inclusion in Theses and Dissertations by an authorized administrator of BYU ScholarsArchive. For more information, please contact scholarsarchive@byu.edu, ellen_amatangelo@byu.edu. 


\title{
THE ROLE OF INSPIRATION IN SCIENTIFIC SCHOLARSHIP AND DISCOVERY: VIEWS OF THEISTIC SCIENTISTS
}

\author{
by \\ Kari A. O'Grady \\ A dissertation submitted to the faculty of \\ Brigham Young University \\ in partial fulfillment of the requirements for the degree of \\ Doctor of Philosophy \\ Department of Counseling Psychology and Special Education \\ Brigham Young University
}

December 2006 
Copyright $\left({ }_{0} 2006\right.$ Kari A. O’Grady

All Rights Reserved 


\title{
BRIGHAM YOUNG UNIVERSITY \\ GRADUATE COMMITTEE APPROVAL
}

\author{
of a dissertation submitted by \\ Kari A. O’Grady
}

This dissertation has been read by each member of the following graduate committee and by majority vote has been found to be satisfactory.

Date

Date

Date

Date

Date
P. Scott Richards, Chair

Timothy B. Smith

Rachel E. Crook-Lyon

Marleen S. Williams

Lane Fischer 


\section{BRIGHAM YOUNG UNIVERSITY}

As chair of the candidate $=\mathrm{s}$ graduate committee, I have read the dissertation of Kari A. O'Grady in its final form and have found that (1) its format, citations, and bibliographical style are consistent and acceptable and fulfill university and department style requirements; (2) its illustrative materials including figures, tables, and charts are in place; and (3) the final manuscript is satisfactory to the graduate committee and is ready for submission to the university library.

Date

P. Scott Richards Chair, Graduate Committee

Accepted for the Department

Aaron P. Jackson Graduate Coordinator

Accepted for the college

K. Richard Young Dean, McKay School of Education 


\begin{abstract}
THE ROLE OF INSPIRATION IN SCIENTIFIC SCHOLARSHIP AND DISCOVERY: VIEWS OF THEISTIC SCIENTISTS
\end{abstract}

\author{
Kari A. O’Grady \\ Department of Counseling Psychology and Special Education \\ Doctor of Philosophy
}

This qualitative research study examined the ways those who identify themselves as theistic scientists and scholars experience inspiration, as defined as divine guidance or influence, in their scientific scholarship and discovery. It also explored participants' beliefs about how scientists and scholars can seek and prepare to receive inspiration in their work. Open-ended surveys of 450 participants from the behavioral and natural sciences and from a variety of religious backgrounds were analyzed for content themes in the areas of experiences with inspiration, preparing to receive inspiration, and further thoughts on inspiration in science. The themes extracted indicated that these scientists and scholars have experienced inspiration throughout all stages of the research process. They also believe that certain practices and virtues, such as openness to inspiration and nurturing a relationship with God, can help scientists and scholars be more prepared to receive inspiration in their work. 


\section{ACKNOWLEDGEMENTS}

I express my gratitude to the participants of this study. I am grateful for their courage and generosity in sharing personal and sacred experiences. I am thankful to my committee for their thoughtful feedback and refinements, and for helping me in my scholarship efforts overall. I express thanks to the undergraduate researchers whose talent, dedication, and rigor made the data analysis possible and the research process more enjoyable. Further I would like to thank Dr. Lisa Miller for auditing the study and for her encouragement.

I express my heartfelt thanks to my family for their constant support as I worked on this project and as I pursue my education. My husband, Tom, and our children Steve, Amanda, Brenna, and Tommy supported me as I devoted long hours in completing my dissertation. I am grateful for their love and the goodness of their spirits. They inspire me.

I would also like to express my gratitude for my chair and mentor Scott Richards. He has been a fundamental part of this study from its inception and has been a coinvestigator throughout it. His belief in me and his standard of excellence have helped me tremendously in my efforts to become a scholar. I also deeply appreciate his friendship and commitment to helping me in my career. I am thankful for his example of spiritual strength and integrity.

Finally and foremost, I am grateful to the Lord for His understanding, mercy, and love in my life. I have felt His guidance and sustaining influence throughout this project. He is the Reason. 


\section{Table of Contents}

List of Tables .....................................................................................................ii

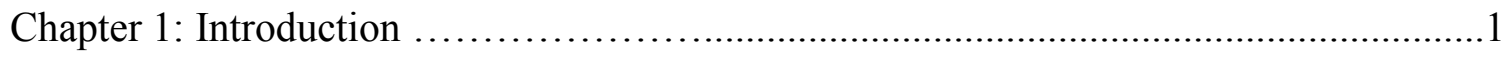

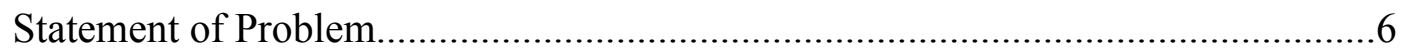

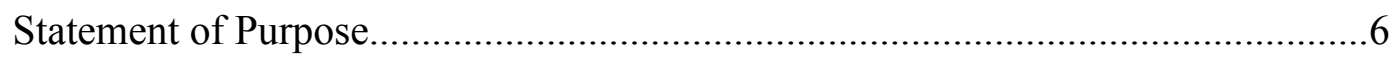

Definition of Terms...................................................................................

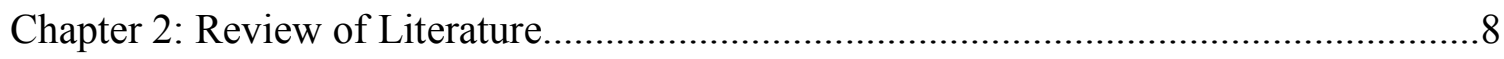

Historical Views of Modern Science.....................................8

Adoption of Naturalism.............................................11

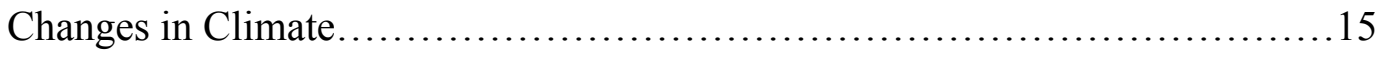

A Theistic View of Science................................................. 16

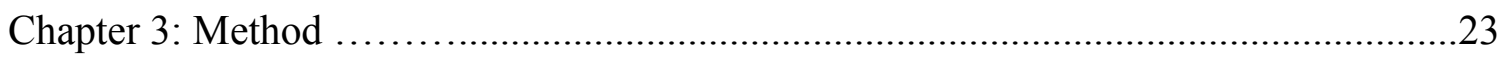

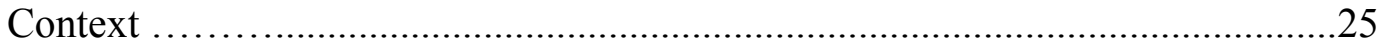

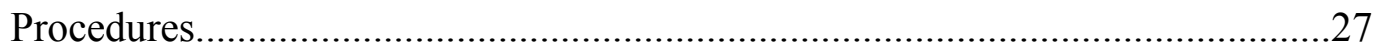

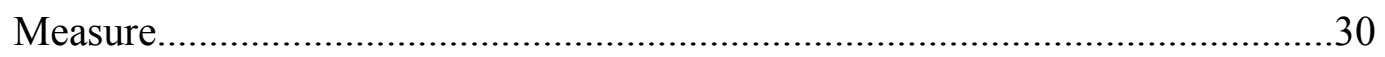

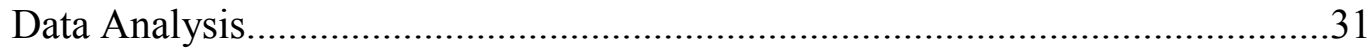

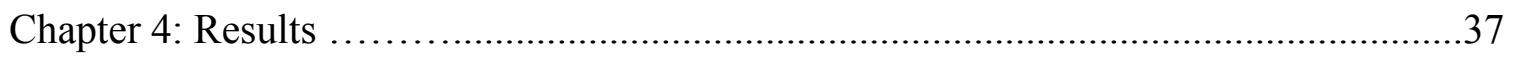

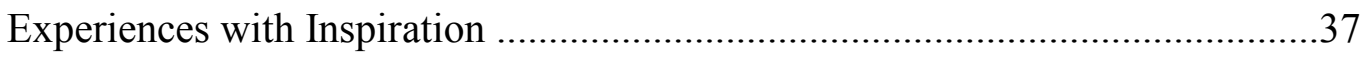

Preparation for Inspiration ..........................................................62

Further Thoughts on Inspiration........................................................... 73

Naturalistic/Atheistic Views of Science ....................................................8

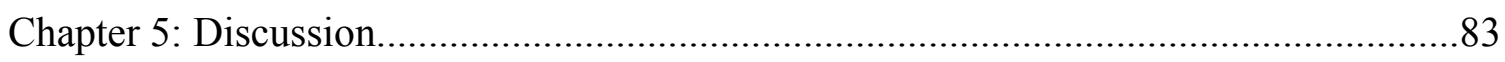

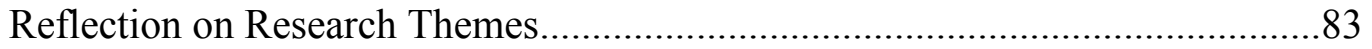


Limitations of the Study.

Recommendations for Further Research.....................................................93

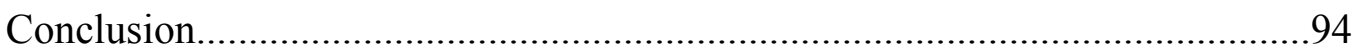

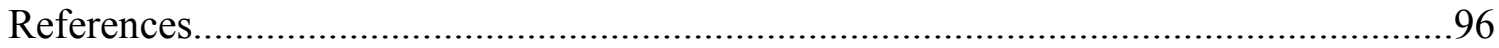

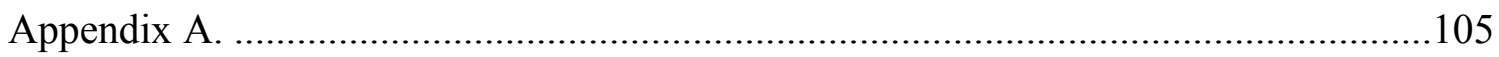

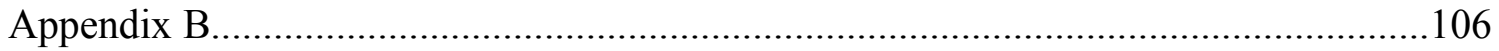




\section{List of Tables}

Table 1. Select characteristics that distinguish quantitative and qualitative

research.

Table 2. Participants' experiences with inspiration in scholarship and

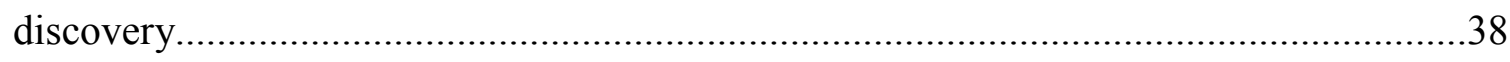

Table 3. Participants' suggestions for future

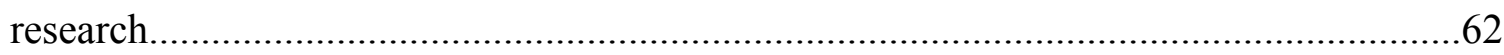

Table 4. Other thoughts respondents had about the role of inspiration in scholarship and

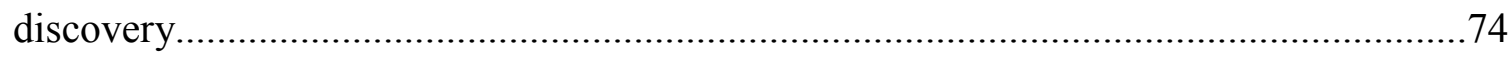




\section{But there is a spirit in man: and the inspiration of the \\ Almighty giveth them understanding.}

- Job $32: 8$

Introduction

During the late $20^{\text {th }}$ and early $21^{\text {st }}$ century an increasing number of scientists and theologians began exploring the connections between science, religion, and spirituality. One significant catalyst for the growth in this dialogue occurred when the Berkeley-based Center for Theology and the Natural Sciences (CTNS), with funding support from the John Templeton Foundation, created a program called "Science and the Spiritual Quest." This program "assembled leading scientists from around the world in private workshops, organized public conferences and telecasts, published books and articles and drew media attention to questions of science-and-religion" (Clayton, 2003, p. 2).

The science-spirituality dialogue has grown to include scholars from many of the natural and behavioral sciences, including astronomy, biology, biochemistry, chemistry, evolution, physics, psychology, and sociology. Theologians and religious scholars from all of the major world religions have also begun to join in the discussion about the role of spirituality in science (Polkinghorn, 2002). Natural and behavioral scientists have started to explore the cosmos, genetics, ethics in science, human functioning, development, and change, through a theistic perspective (e.g., Dembski, 1999, 2001; K.R.Miller, 1999; Mooney, 1996; Numbers, 2003; Polkinghorne, 1998; Shafranske, 1996; Sperry, 2005; Worthington, 2001, 1998).

Although studies suggest that scientists tend to be less religious and spiritual than the general population, they seem to be more religious and spiritual than many might 
think (Astin \& Astin, Ct; Bartlett, 2006; Gross \& Simmons, 2006). A recent study examined the religious and spiritual beliefs of 1,646 academic behavioral and natural scientists at twenty-one major universities in the U.S. The results from the study showed that a surprising number of scientists are interested in spirituality ( $69 \%$ of behavioral scientists and $66 \%$ of natural scientists) and that $48 \%$ identify with a specific faith tradition (Ecklund, 2006). Of those scientists who do view religion and spirituality as important, many are becoming actively engaged in encouraging a dialogue between the scientific community and the lay public. In another study conducted with a stratified random sample of 1,643 professors from a variety of colleges and universities, $81 \%$ considered themselves spiritual and 53\%-60\% professed a belief in God (Gross \& Simmons, 2006).

The Higher Education Research Institute (HERI) at University of California Los Angeles (UCLA) recently conducted a large scale study investigating the role of spirituality in higher education. Among other areas and populations of investigation, the study surveyed 40,670 members of the faculty at 421 colleges and universities nationwide. Of the faculty surveyed, $81 \%$ consider themselves to be spiritual people, $64 \%$ said that they consider themselves to be a "religious person," $61 \%$ reported that they pray and/or meditate, $69 \%$ seek out opportunities to grow spiritually, and $68 \%$ engage in self-reflection (Astin \& Astin, Ct). Additionally, 47\% of participants have a goal of integrating spirituality into their lives.

Such studies provide evidence that many scientists believe in God and have spiritual interests. An important, but largely unexplored area of investigation to date is the ways spiritual phenomena impact our capacity for gaining scientific knowledge. The 
scholarly and scientific discovery process is typically conceived as a rationalobservational process. Scholars and researchers use reason to form their theories and observation to empirically test them. While this conception of the scientific process is important it may be incomplete. Possible contributions of intuition and inspiration to scientific discovery and scholarship have been obscured by the restricted scope of this traditional view.

Some scientists and scholars have also acknowledged inspiration as a contributing factor in the scientific and creative process. For example, Blaire professor of Geoscience at Princeton University, John Suppe said, "There have been many cases in which I have made serious decisions in my science that are not just rationally looking at the science and opportunities, but where I have felt that the Lord wanted me to go and do something specific. I did it and I didn't really see any particular reason for doing it, but it was fruitful" (Suppe, 2001, p. 223). After working rigorously on the problem at hand, the famous German physicist, Helmholtz, would suddenly experience insights that came to him "unexpectedly without effort, like inspiration" (quoted in Wallas, 1926, p. 80). In Albert Einstein's biography, R. W. Clark wrote: “Today, two-thirds of a century after Einstein posted the manuscript of his paper to Annalen der Physik the dust is still stirred by discussion of what inspired him" (Clark, 1971, p. 74).

Kekule von Stadonitz, a German chemist who discovered the cyclic structure of benzene, "had a visionary experience in which he perceived the ends of swirling molecules bending and touching one another to form a ring” (Bergin, 1979, p. 451). In discussing inspirational dreams, psychiatrist Kenneth Colby stated that "in the final analysis no one knows where great ideas come from - they are a gift from God" (quoted 
in Bergin \& Strupp, 1972, pp. 280-281). Allen E. Bergin, a distinguished academic clinical psychologist, suggested that "extraordinary insights of scientists, scholars and artists come by revelation in the context of disciplined and educated searching...via a heavenly process" (Bergin, 1979, p. 455).

In addition to stressing the importance of inspirational, intuitive influences in the scientific process, some scientists have suggested that there are specific stages that scientists go through in preparing to experience this influence. For instance, psychologist and Nobel Prize winner, Neal E. Miller said that the preparatory phase of the scientific process is the stage in which scientists prepare for and are open to receive intuitive insights in their investigation of a phenomenon (Bergin \& Strupp, 1972).

After analyzing the experiences of several scientists and other great thinkers, Graham Wallas (1926), a philosopher and psychologist, theorized that discoveries and new ideas originate through a process of four stages: the preparation stage, the incubation stage, the illumination stage, and the verification stage. Wallas (1926) also stated that "If we accept this analysis, we are in a position to ask to what degree, and by what means, we can bring conscious effort, and the habits which arise from conscious effort, to bear upon each of the four stages" (p. 82). In support of this idea, Wallas (1926) shared scientist and author of Science and Methods, Henri Poincare's perspective that "inspiration [is] the fruit of unconscious work" (p. 81).

Some scholars have suggested that scientists who make significant discoveries seem to share certain attributes and may be more qualified or prepared to receive insights into extraordinary or new phenomena (Mansfield \& Busse, 1981; Simonton, 2004). Scholars who study creativity in science have noted that creative scientists tend to have a 
need for the novel and a willingness to push past traditional constraints to pursue the scientific process in unusual ways (Mansfield \& Busse, 1981). They tend to work hard on the problem at hand, and then create space in the process for exploration, surprises, or serendipity (Merton \& Barber, 2004; Roberts, 1989; Shapiro, 1986). They are more willing than many scientists to trust their "gut" or inner experience (Mansfield \& Busse, 1981; Simonton, 2004).

It appears that some scientists do pray as a way to prepare to receive inspiration or divine guidance in their work. For example, several years ago the Templeton Foundation and the American Scientific Society hosted a conference entitled, Asking the Right Questions: Christian Faith and the Choice of Research Topic in the Natural and Applied Sciences. The conference encouraged scientists to explore possible guidelines for selecting research topics. These guidelines included engaging in thoughtful inquiry and prayer to find research topics and guidance about how to proceed with their research (Templeton, 2000). Other scientists have encouraged scientists to be humble and willing to allow God to guide them to new discoveries and important insights (Suppe, 2001).

Despite the many antidotal reports reported above concerning the role of inspiration in science, little research has been conducted that explores this topic. No study to date has investigated how modern-day theistic scientists experience inspiration in the scientific discovery process, including ways they prepare to experience this influence in their work. This study will help contribute to this important but neglected area of investigation and thus provide insights into the ways inspiration can augment the traditional conception of the scientific process. 


\section{Statement of Problem}

Despite the recent increase in interest and activity in spiritual phenomena in scientific endeavors, there is little documentation about the role inspiration plays in science. Although some scientists have shared excerpts of divine influences in their discoveries to date there has been no systematic investigation into the role inspiration plays in the scientific process in the lives of contemporary scientists. There is a dearth of studies which have examined how scientists seek or prepare themselves to receive inspiration in their work. Although the scientific process is typically explored by scientists of the natural sciences, it is appropriate for a student of counseling psychology to investigate this topic as well. Counseling psychology doctoral training programs are designed to train students in the scientist-practitioner model. Scientist-practitioners are encouraged to contribute to scientific knowledge and advancement. As scientists interested in the study of human behavior, counseling psychologists are qualified in some unique ways to contribute to the study of the human endeavor of science.

\section{Statement of Purpose}

In order to better understand the role of inspiration in scientific scholarship and discovery, we considered it essential to more adequately document this phenomenon in the lives of contemporary theistic natural and behavioral scientists. The general purpose of the study was to learn more about the views of theistic scientists regarding the role of inspiration and intuition in the scientific process.

The specific aims of this study were to answer the following questions:

1) In what ways do the scientists who identify themselves as theistic in our sample experience inspiration in their scientific scholarship and discovery? 
2) What do the scientists who identify themselves as theistic in our sample recommend other scientists do to qualify to receive inspiration from God?

\section{Definition of Terms}

To help clarify the use of various terms that are used throughout the document, a few key terms are defined below. These definitions are not definitive, but rather represent the usage of the terms in the document and study.

\section{Theism}

Theism has been defined as "a belief in one God who is personal, worthy of adoration, and separate from the world but continuously active in it" (Palmer, Keller, Choi \& Toronto, 1997, p. 7). Judaism, Christianity, Islam, Zoroastrianism, and Sikhism are the major monotheistic religions. Monotheism is the belief in one Supreme Being or one Supreme God (Griffin, 2001; Richards \& Bergin, 2005). Along with this belief, most people who identify themselves as theistic believe that there is a life beyond the material, sensational world. They also assume that God created and continues to interact with humanity (W.R. Miller, 2005). The majority of participants in this study have identified themselves as theistic, which means that they believe in a personal, active God. The term theism is used throughout the document mostly in reference to theistic science.

\section{Naturalism}

Naturalism is a metaphysical belief currently endorsed by many in the scientific community. It has been defined as the belief that "natural laws and/or principles ultimately govern the events of nature, including our bodies, behaviors, and minds" (Slife, 2004, p. 45). Further naturalism is a belief that humans and the universe can be fully explained and understood without reference to God or spiritual phenomena 
(Richards \& Bergin, 2005). Naturalistic science has been adopted in modern science as the preferred way to investigate; however, a number of post-modern and theistic scientists are beginning to question the necessity of many of the constraints associated with naturalism (Griffin, 2001; Slife, 1999, 2004).

Inspiration

Although inspiration has been defined by many in naturalistic terms, such as one being inspired by nature or the performance of another, the term inspiration that is used in this study refers to inspiration as an influence or experience of God. To help clarify the use of the term when surveying the participants in the study, the term was defined in the cover letter as a "divine guidance or influence exerted directly on the mind and soul of humankind" (The American Heritage ${ }^{\circledR}$ Dictionary of the English Language, Fourth Edition, 2000, Houghton Mifflin Company). This definition appropriately represents the use of the term throughout the study. 


\section{Review of Literature \\ Historical Views of Modern Science}

Some scholars have suggested that the origins of modern scientific thought can be traced to the mediaeval period (Burtt, 2003; Leon, 1999; Lindberg, 2003b). Religious dogmatism and intellectual suppression were endemic of the early medieval period (Lindberg, 2003b), but the latter part of this era spawned the creation of universities, the translation of texts (including the Bible) into the common person's language, and the introduction of a new class of intellectuals referred to as "theologians-natural philosophers." These philosophers were interested in investigating the natural order of the universe, while still adhering to their faith in religious doctrine. The increased interest in the natural world encouraged multiple interpretations of the Bible, and various speculations about the workings of the world causing many to become discontented with traditional religious explanations of astronomical, biological, and geographical phenomena (Lindberg 2003a).

In response to the changing climate, the Renaissance era emerged. A parallel movement, the Protestant Reformation, ushered in a period of intensifying criticism of remaining religious dogma and oppression. Individuals challenged religious authority and considered alternate ways of discovering truths. Thus, overlapping the late Renaissance was the development of scientific experimentation (Delaney \& Clemente, 2005b; Brooke, J.H. 1996; St. Claire 1985, Keener, 1983).

Early philosophers also played a role in segregating science and religion. Prior to the Renaissance period, innovative scientific philosophies sustained and supported biblical interpretations of the creation and the universe. During the Renaissance era, 
however; philosophers began to confront biblical understandings. Galileo, for instance, challenged biblical interpretations of the earth as the center of the universe. In response to the Christian church's attempts to squelch scientific inquiry, Galileo affected a distinct separation between science and religion. He made peace with the church by giving religion the why of intellectual inquiry and science the how (Blackwell, 2002;

Polkinghorne, 1998; St. Claire 1985; Keener, 1983). Philosophers and scientists increased their emphasis on causal factors of life events rather than the purpose of them (Leon, 1999). This distinction of focus created a vast chasm between spirituality and science leaving little or no ground for science and religion to share in a scholarly dialogue. Science, reason, reformation and renaissance all fueled the age of Enlightenment (Delaney \& Clemente, 2005b; Lindberg 2003b; Polkinghorne, 1998; St. Claire 1985; Keener, 1983).

The atmosphere of the Enlightenment era invited previously excluded individuals to engage in public intellectual exchanges. A number of scholarly clubs such as scientific societies, political clubs, and reading clubs were formed for the purpose of intellectual interaction. Scholars of the time fought for more freedom of press by publishing in professional journals, newspapers, periodicals, and scholarly texts. A turning from religious dogma to faith in human acumen and the ability to reason characterized this period in history. Old, unquestioned traditions were being challenged by critical thought and scientific advancement. Religious authority was under the scrutiny of intellectuals who were looking for a cause and effect in all aspects of humanity (Fergren, 2002; St. Claire 1985; Keener, 1983). 
The life and philosophies of Pierre-Somon de LaPlace serve as an example of the zeitgeist of this time. LePlace renounced his training as a cleric to study mathematics and astronomy. He abandoned God in all of his theories, and when asked by theists why God was never mentioned in his cosmological explanations, leading scientist of his time, LaPlace answered, "I have no need of that hypothesis" (Numbers, 2003, p. 273). This era gave birth to the scientific revolution, psychology, and new views of history and philosophy (Delaney \& DiClemente, 2005).

\section{Adoption of Naturalism}

The philosophical divorce of science from religion was associated with the acceptance of naturalism. By the end of the nineteenth century God was excluded from scientific consideration and atheistic naturalism reigned supreme in both the natural and behavioral sciences (Polkinghorne, 1998; Delaney \& DiClemente, 2003a). Most behavioral scientists, insecure about their standing in the scientific community, boldly denounced religion and wholeheartedly embraced not only naturalistic methodologies but also the philosophy of scientific naturalism as well (Delaney \& DiClemente, 2003a). Spiritual aspects of humanity and the world in which they lived were obscured. Referring to this, Numbers (2003) noted that, "Under the naturalistic gaze of social scientists the soul dissolved into nothingness, God faded into an illusion, and spirituality became.... a merely incidental phosphorus" (p. 282).

Although these historical "landmarks" may help us better understand the "spirit of the times" of various eras, the presuppositions, or unquestioned assumptions of these times are often more epically revealing. Presuppositions dogmatically assume truth without explicitly investigating the reasons behind the assumptions. A presupposition is 
not a reality unto itself but rather an ideology (Dembski, 1999; Johnson, 1993). One of the presuppositions of the twentieth century was that science was the supreme authority on what is real. Along with this assumption came the assertions of naturalism that human beings and the universe can be understood and eventually fully explained without including God or divine influence in scientific theories or in the interpretation of research findings (Polkinghorne, 1998; Honer \& Hunt, 1987; Leahey, 1991). In addition, naturalism asserts that only phenomena that can be observed directly or measured through scientific instruments are real (Richards \& Bergin, 2005).

Naturalism became the filter of truth for the sciences. Only those investigations which adhered to the tenants of naturalism were validated by science, and this conception of science was considered the only valid way of knowing what is and is not real (Davis \& Collins 2002; Honer \& Hunt, 1987; Leahey, 1991, Richards \& Bergin, 1997, 2005). Modern scientists' commitment to discovering truths became delineated by a greater loyalty to the tenants of naturalism. The naturalistic view of science escaped its own rigorous criteria of evaluation, thus creating an insufficient theoretical and methodological framework for discovering truths (Dembski \& Kushiner, 2001, Griffin, 2001: Mooney, 1996). Those who tried to argue against naturalism were marginalized for not fitting into these presupposed definitions of reality.

Naturalism's virtually unchallenged dominance as the only acceptable framework for "true" scientific investigation has obscured other useful avenues of inquiry, leaving many important aspects of the universe unexplored (Dembski, 2002; Slife, Hope, \& Nebeker, 1999; Johnson, 1993). Although the Enlightenment era offered new ways of thinking unconstrained by religious dogma, the narrow view of naturalism restricted 
intellectual inquiry and discussion in other ways (DiClemente \& Delaney, 2005; Richards \& O’Grady, 2003; Johnson, 1993).

Considering the unchallenged presuppositions of modernistic science, Johnson (1993) stated:

Modernistic science is just as imperialistic as it is naturalistic. When science gained authority to tell the culture "how things really are," it told the culture that reality excludes God, because God is inconvenient to a science that aspires to tell a grand metaphysical story of a naturalistic universe.” (p. 201)

Some scholars refer to the naturalistic system of beliefs adopted by the scientific community, as the religion of scientists or scientism (Crouch, 2002; Mooney, 1996). Dr. Thomas Dixon (2002) shares the three natural science "principle doctrines" in his article "Scientific Atheism as a Faith Tradition." The three principles are mechanism, the centrality of natural selection, and the contingency of evolutionary outcomes. All three principles decidedly exclude God and spiritual realities.

In their book, A Spiritual Strategy for Counseling and Psychotherapy, Richards and Bergin (2005) discuss the belief system of modern behavioral science. Some of the modernistic science assumptions they mention are naturalism and atheism, determinism, universalism, reductionism and atomism, materialism and mechanism, and empiricism. The basic premises of these assumptions are that there is no God, there is no agency, phenomena is only real if it is repeatable and generalizable, species and cosmic entities can be explained best by reducing them to their smallest components, humans are biological beings without a spirit or soul, and observation is the only true form of gaining knowledge (Richards \& Bergin, 2005). 
Not only does the framework of naturalism exclude the exploration of spiritual and religious influences on humans and their world, it also circumvents insights that might be gained through unseen influences such as intuition or inspiration, thus restricting the methods we can use for discovering truths. This narrow view of what qualifies for study and what can help us find answers in our studies has constrained the opportunity for scientists to investigate spiritual realities and for religious perspectives to inform scientific endeavors (DiClemente \& Delaney, 2005a; Richards \& O'Grady, 2003; Jones, 1994).

Johnson (1993) stated that the biases of naturalism stifle possible areas of inquiry that the mind might otherwise consider. In his view, science has an obligation to free itself from such unnecessary restrictions:

Science always has to fight the prevalent bias of an age if it is to be free to follow the evidence where it leads. In the past geology had to fee itself from religious bias so it could consider possibilities like an old earth or the occurrence of ice ages...That job was accomplished long ago, and now scientific thought is restricted by naturalistic bias. Methodological naturalism is a bias in the sense that it constricts the mind, by limiting the possibilities open to serious consideration. Theistic realism opens the mind to additional possibilities, without preventing the acceptance of anything that really is convincingly demonstrated by empirical evidence. (pp. 217-218)

Naturalistic assumptions are not necessary criteria for true science to exist. In fact, the origins of science are not grounded in naturalism. It has taken "centuries, indeed millennia, for naturalism to dominate the study of nature" (Numbers, 2003, p. 265). 
These assumptions inhibit scientists from investigating many of human's most important experience, thus unduly limiting people's understanding of unseen, but real phenomena that influences human behavior and natural occurrences (Richards \& Bergin, 2005; Honer \& Hunt, 1987).

\section{Changes in Climate}

Despite the virtually unchallenged presuppositions of the twentieth century, naturalism is not the only way for serious scholars to be scientific, nor the only legitimate perspective for considerate clinicians to conceptualize their therapeutic orientations. Many scholars have begun to challenge the suppositions of naturalism (Griffith, 2000; Jones, 1994; Richards \& Bergin, 1997, 2005; Slife, 2004) and call for a scientific worldview sophisticated enough to include God and spiritual influences.

Understanding that naturalism is an ideology rather than an uncontestable, rigorously proven and justifiable necessity of science, may help scientists and scholars remove simplistic and superfluous constraints on the philosophies that support worldviews and under-gird the scientific discovery process. This understanding invites respectful dialogue from a variety of perspectives. By eradicating unduly restrictive viewpoints, scientists and scholars can be more open to creative, intuitive, inspirational processes.

In recent years the scientific climate has begun to warm towards religion and spirituality. This change in atmosphere has opened the door for multiple ways of knowing and increased areas of scientific exploration. During the late $20^{\text {th }}$ and early $21^{\text {st }}$ century an increasing number of natural scientists and theologians began exploring the connections between science, religion, and spirituality. An important, but largely unexplored area of 
investigation is the ways spiritual phenomena impact one's capacity for gaining scientific knowledge. However, the current change of climate in scientific inquiry makes such an investigation valuable and viable.

\section{A Theistic View of Science}

Scientists' and researchers' methods and practices are largely influenced and constrained by their theological and philosophical foundations. The best scholarship and most effective work with clients comes from a conscientious awareness of and consistency between what scientists and psychotherapists believe and do-consistency between their theology and their practice (Guiffrida, 2005; Arthur, 2001, Fear \& Woolfe, 1999). If scientists accept the reality of God, but work from a godless framework, they are likely to stumble over their inconsistencies in their efforts to discover and to help. Scientists who believe in God may work more effectively from a theological foundation congruent with their theistic worldview.

In recent years there have been a number of natural and behavioral scientists and philosophers who have proposed theistic views of science (e.g. Griffin, 2001, Johnson,1993; Peacocke, 2001; Plantinga, 1993; Polkinghorne,, 1998; Richards \& Bergin, 2005; Whitehead, 1967). Although these scholars each conceptualize theistic science somewhat uniquely, they have in common the theological foundation that God exists, and that divine influences can have a place in science. According to Richards and Bergin (2005), a theistic view of science may also include a number of other theological and philosophical perspectives, including theistic views of epistemology, the scientific process, and research methodology. 
In contrast to the positivistic model associated with naturalism; which asserts that knowledge can only be gained through empirical, experimental, quantitative methodologies, the assumptions of theistic science endorse methodological and epistemological pluralism (Burtt, 2003; Leon, 1999; Richards \& Bergin, 2005; Slife \& Gantt, 1999). Theistic perspectives of science do not necessarily oppose scientifically parsimonious explanations of humans and their world, but rather acknowledge that "simplicity in the face of ...complexity is not virtuous but can be misleading" (DiClemente \& Delaney, 2005a, p. 277).

Epistemological pluralism allows for multiple ways of gaining knowledge. A theistic perspective considers sense experience or empiricism to be a legitimate and helpful way to gain insights, but it does not endorse the naturalistic perspective that empiricism is the only way to gain knowledge. The assumptions of theism assert that reason, authority (including religious authority/scriptural texts), and intuition/inspiration are additional, important, and valid ways of gaining scientific insights (Richards \& Bergin, 1997, 2005; Sue, 1999). According to a theistic perspective, inspiration does not conflict with the traditional conception of the scientific method, but rather enhances it, making it more complete (Jones, 1986; Padgett, 2002). Philosopher Kenneth Kemp (1998) suggests that faith in God can "get us to some truths that would otherwise be inaccessible to us" (p.466).

Methodological pluralism expands how and what phenomenon can be studied. Although it is essential that rigorous standards of research be set and adhered to, by reducing the lens of what can be investigated and how it can be investigated too narrowly scientists are likely to miss many important discoveries that could be beneficial to 
humankind. By broadening methodological options to include both quantitative and qualitative research paradigms, behavioral scientists expand the windows of what can be studied and how the knowledge can be investigated. The selection of research design to be used should be thoughtfully guided by which method will most effectively help the researcher investigate the particular area of interest. This comprehensive view of research may provide a more valid means for the scientific study of spiritual and religious phenomena (Slife \& Gantt, 1999).

A theistic perspective of science encourages the study of spiritual influences in science as well as maintains the view that spiritual influences can be used to better understand phenomena under scientific investigation. According to a theistic view of science, God may enlighten scientists in their efforts to make discoveries that will benefit society. In discussing a theistic view of the scientific process, Richards and Bergin (2005) stated the following:

An important contribution of the theistic view of epistemology to our understanding of the scientific process is that it affirms that intuitive, inspirational ways of knowing may be a part of the scientific discovery process. According to the theistic worldview, many great ideas, creations, and discoveries are gifts from God. Through intuition and inspiration, God enlightens human beings to make great discoveries and creations to benefit humanity (p. 319)

The experience of inspiration has often been overlooked because the naturalistic constraints on the scientific process and epistemology in general have constrained the ways scholars conceptualize and describe this stage of the scientific process. Many scholars have acknowledged a more spontaneous stage of research that seems to generate 
extraordinary insights. Some scholars have attempted to capture and explain this stage or experience from a naturalistic perspective. For instance, in discussing where scientific understanding comes from Wallas (1926) described four important stages in the discovery of new insights. He described these stages as (a) the preparation stage in which one systematically and rigorously analyzes the problem, (b) the incubation stage in which the scientists lets the idea rest or "simmer," (c) the illumination stage in which flashes of insight appear and are often preceded by a feeling of "intimation" that the illumination was coming, and (d) the verification stage in which the new insight is tested and refined. The illumination stage seems to correspond with the inspiration aspect of the theistic perspective of the scientific discovery process. The author of Creativity: Flow and the Psychology of Discovery and Invention, Mihaly Csikszentmilhalyi (1996), outlined the stages of discovery in a similar way in his study of flow in discovery and invention. He referred to the incubation stage as the most creative stage of the discovery process and suggested that what takes place during this stage of discovery "defies ordinary analysis and evokes the original mystery shrouding of the work of genius: One almost feels the need to turn to mysticism to invoke.....an explanation" (p. 98).

Similar to Wallas and Csikszenthihalyi's conceptions of scientific discovery stages, Neal E. Miller stated that there are two phases of research: the discovery phase and the proof phase (Bergin \& Strupp, 1972). It is during the discovery phase that scientists and researchers can be open to creative, inspirational, intuitive ways of gaining insight. Miller is cited by Bergin and Strupp as having said the following about the creative discovery process: 
During the exploratory phase....I am quite free-wheeling and intuitive-follow hunches, vary procedures, try out wild ideas, and take short-cuts. During it, I usually am not interested in elaborate control; in fact, I have learned to my sorrow that one can waste a lot of time on designing and executing elaborate controls for something that is not there. After I believe that I have discovered a phenomenon and understand something about it comes the next phase of convincingly and rigorously proving this to myself and to the rest of the scientific community. ( $\mathrm{p}$.

In most cases scholars interested in creativity and flow in science have offered naturalistic explanations for this aspect of discovery.

A theistic view of science broadens our understanding of this stage of the process. From a theistic perspective, this spontaneous, insightful stage may be in part due to God's influence in the process. It may be that God inspires researchers and scientists as they work on the problem at hand. It is possible that the need for mystical explanations is due to the transcendent influences on the process. Despite the influential voice of naturalism, some scientists have shared ways in which they have felt mystical or divine influences in their scientific discoveries.

In his book The Mind of God: The Scientific Basis for a Rational World, physicist, Paul Davies (1992) says that mystical or inspirational experiences can at times provide a “type of shortcut to truth” (p. 228). In this same book, Davies shares Roger Penrose's description of mathematical inspiration as a sudden "breakthrough" into another realm. Another mathematician, Kurt Godel asserted that we should have as much confidence in intuition as we do in sensory perception. As an example of this suggestion, he relates an 
experience with inspiration in which he was able to perceive through revelatory means mathematical objectives by shutting off his other senses (Godel, 1990).

Physicist Fred Hoyle described an occasion in which a particularly puzzling math equation needed to conceptualize a cosmological theory of electromagnetism was solved through what he describes as a religious experience. He related, "My awareness of the mathematics clarified, not a little, not even a lot, but as if a huge brilliant light had suddenly been switched on. How long did it take to become totally convinced that the problem was solved: Less than five seconds" (1981, p. 43).

According to a theistic view of science, scientists can be inspired by God or receive "flashes of insight" from God as part of the scientific process. This view also suggests that a willingness to include inspiration as an important part of the method may allow scientists to experience and benefit from these aspects more fully (Templeton, 2000).

For instance, geoscientist John Suppe (2001) encouraged scientists to include God in every stage of the research and discovery process. He suggested that prayer, humility, and willingness to follow God's will and guidance can greatly enhance the scientific process. He related an experience in which a very large earthquake had occurred in Taiwan on a fault he had already studied extensively in previous years. He had no desire to return to the site and study it further. He decided to pray about his decision to not return to Taiwan. Despite his own wishes, he felt God wanted him to go to Taiwan and conduct research there. He followed this inspiration. He related:

As a result of my trip, some unexpected and tremendous new things have developed scientifically. We are making some very exciting new discoveries.... I 
would say that most of the major discoveries I've had in science have been handed to me as a gift.... They do not represent the ways my colleagues make decisions in science. This is finding out God's will in highly specific situations. (p.223-224)

According to a theistic view of science, inspiration is an important part of the scientific process, but this view affirms the need for subjecting insights gained through inspiration to the same level of rigorous testing as insights gained by other, more traditional means (Richards \& Bergin, 2005). The traditional view of the scientific process has proven helpful to researchers and scientists in their scholarship and discovery. A theistic view of the scientific process may enhance these processes and provide additional insights that may have been missed through a purely rationalobservational process. 
Method

This study was conducted qualitatively, meaning it adheres to the characteristics of qualitative research. Table 1 below contrasts the distinguishing characteristics of both quantitative and qualitative research designs. In qualitative research the researcher's perspective and values are part of the process. The modern view of science that investigators can somehow remove their values or perspectives and maintain an "objective" view of the subject under study is rejected (Kazdin, 2003; Johnson \& Christensen, 2004). It is considered impossible and undesirable to remove oneself from the study in a supposed "objective" stance. Kazdin (2003) said the following in regards to qualitative research characteristics:

The investigator is part of the interpretation in light of his or her perspective; the perspective is made explicit, but it can never be removed; empathy of the investigator is the key to deeper understanding....The participants are not objects...the experience described and understood cannot be removed from the one who describes (the experimenter). (p.335)

From this view it is assumed that all researchers bring their values and perspectives to the investigation. Values may help researchers understand the participants' experiences more accurately than if researchers were somehow able to remove themselves from the process (Slife \& Gantt, 1999). For instance, a theistic researcher trying to understand theistic participants' responses may be more likely to capture the nuances of the responses better than an investigator unfamiliar with theism. Likewise the reporting of the findings may more appropriately represent the meaning of the respondents when the researcher is able to allow their values to be part of 
Table 1

Selected Characteristics that Distinguish Quantitative and Qualitative Research

\begin{tabular}{|c|c|c|}
\hline Characteristic & Quantitative Research & Qualitative Research \\
\hline Goals & $\begin{array}{l}\text { Test theory and hypothesis; } \\
\text { identify causal relations, seek } \\
\text { group differences or patterns }\end{array}$ & $\begin{array}{l}\text { Describe and interpret } \\
\text { experiences; provide new } \\
\text { insights, describe and explain } \\
\text { with few or no initial hypotheses; } \\
\text { generate theory }\end{array}$ \\
\hline Use of controls & $\begin{array}{l}\text { Usually, control or comparison } \\
\text { groups are included to address } \\
\text { threats to validity }\end{array}$ & $\begin{array}{l}\text { No control group. The goal is to } \\
\text { elaborate the richness of a } \\
\text { particular group and the } \\
\text { commonalities differences that } \\
\text { may emerge within that group. }\end{array}$ \\
\hline Role of subject & $\begin{array}{l}\text { The subjects are the objects of } \\
\text { study, the people who provide the } \\
\text { data; the subjects do not reflect } \\
\text { on the data or help the } \\
\text { experimenter make sense out of } \\
\text { the results }\end{array}$ & $\begin{array}{l}\text { The participants are not objects; } \\
\text { the experimenter and subjects } \\
\text { become one in the sense that the } \\
\text { experience described and } \\
\text { understood cannot be removed } \\
\text { from the one who describes }\end{array}$ \\
\hline Role of investigator & $\begin{array}{l}\text { Minimize the investigator's role; } \\
\text { the perspectives, views, and } \\
\text { feelings of the investigator are } \\
\text { reflected in the hypotheses or } \\
\text { focus of the study, but not in the } \\
\text { methods, presentation of the } \\
\text { findings, nor interpretation of the } \\
\text { data; the investigator is detached } \\
\text { to the extent possible }\end{array}$ & $\begin{array}{l}\text { The investigator is part of the } \\
\text { interpretation in light of his or her } \\
\text { perspective; the perspective is } \\
\text { made explicit, but it can never be } \\
\text { removed; empathy of the } \\
\text { investigator is encouraged as a } \\
\text { key to deeper understanding; the } \\
\text { investigator is engaged rather } \\
\text { than detached and can understand } \\
\text { better to the extent that meaning } \\
\text { of the situation is experienced }\end{array}$ \\
\hline Data evaluation & $\begin{array}{l}\text { Statistical analyses to find } \\
\text { patterns, averages, to control } \\
\text { influences further, to identify the } \\
\text { impact of variables on each other } \\
\text { and on an outcome }\end{array}$ & $\begin{array}{l}\text { Literary, verbal, nonreductionist, } \\
\text { go from description to } \\
\text { interpretation to identify themes } \\
\text { to bring new qualities to light. } \\
\text { Systematically identify themes } \\
\text { and ways of categorizing } \\
\text { experiences for purposes of } \\
\text { presentation }\end{array}$ \\
\hline A major contribution & $\begin{array}{l}\text { A new theory, hypothesis, or } \\
\text { relation is brought to light that } \\
\text { will increase our understanding } \\
\text { of the phenomenon }\end{array}$ & $\begin{array}{l}\text { Our understanding of the } \\
\text { experience is elaborated and } \\
\text { brought to light in depth as well } \\
\text { as in ways that extend our } \\
\text { understanding }\end{array}$ \\
\hline
\end{tabular}

Note: Table adapted from A.E. Kazdin (2003). 
the interpretation - "empathy is the key to deeper understanding” (Kazdin, 2003).

Further, it is possible that when researchers and those being researched share similar values, the researchers may have more credibility to the participants. They may be more willing to share their experiences freely when knowing the researchers respect and understand their perspective.

Although researchers' values and perceptions may close some doors of investigation, it is likely that they open up others. For instance, a theistic researcher may be more willing to look at spiritual subject matter that would have likely been left unexplored by atheistic or agnostic investigators. The investigators in this study did try to protect against blind spots by asking open-ended questions to allow participants to speak for themselves and their responses were shared through direct quotations. Further multiple coders and an outside auditor who did not have preconceived notions about what the results should be were used to help analyze the responses.

\section{Context}

The setting of the study was Brigham Young University. BYU is privately owned by The Church of Jesus Christ of Latter-day Saints (LDS). The LDS church has a worldwide membership of over 12.5 million (Watson, 2006). The LDS church is a theistic religion that adheres to the belief that God inspires humans. This study is being conducted from a theistic perspective. A theistic perspective asserts that God exists and has an influence in the world. Monotheism states that there is only one God or Supreme Being. There are five major monotheistic world religions: Judaism, Christianity, Islam, Zoroastrianism, and Sikhism. Nearly $60 \%$ of the world's population adheres to a theistic worldview. There are approximately 260 million Christians (nearly $85 \%$ of the 
population), 6 million Jews, and 4.5 million Muslims in North America (Richards \& Bergin, 2000, 2005; Polkinghorne, 1998). All of the monotheistic religions adhere to a general belief in God and that God does inspire human beings. With an interest in learning about inspiration from scientists from a variety of religious backgrounds, this study was intentionally designed to include participants from a variety of religious affiliations as well as those who identify themselves as belonging to no particular religious denomination.

Brigham Young University is located in the Western United States with a population of nearly 30,000 students from over 120 countries throughout the world (Brigham Young University, Ct). The setting of the study had some influence on the topic of the study selected and the nature of the investigation. Brigham Young University may have a greater openness to the study of spiritual or religious phenomenon and an increased willingness to support a theistic viewpoint of science than many secular universities. The initial sample of participants was selected from Brigham Young University. To help balance the findings and increase the breadth of insight gained, two additional samples of participants were selected from more diverse backgrounds. Overall, the majority of the respondents in this study were not affiliated with Brigham Young University.

This study was conducted in collaboration with the dissertation chair who was the co-investigator. The principle investigator and dissertation chair approached the study from a theistic viewpoint. They believe that God does exist and interacts with the world. In addition, they believe that God is interested in and may assist scientists in their scholarship and discoveries. They also theorized that some scientists may have 
experienced inspiration in their work and that there may be specific steps these scientists may have taken to help them prepare to receive this influence in their scholarly endeavors. Prior to the study, the investigators did assume that God can and does inspire scientists, but they had very few notions about how scientists might experience this inspiration. There is little written about how scientists experience inspiration in their work, so the investigators were open to and interested in learning more about the process from theistic scientists. In addition, the principle investigator is a student of counseling psychology, and the dissertation chair is a professor of counseling psychology. Their background in the behavioral, as opposed to the natural sciences, likely influenced the way they conceptualized and carried out the study. The scientific process is typically explored by scientists of the natural sciences; however, a student and professor in the behavioral sciences are likely a good fit for understanding how humans experience the scientific process because they have been trained in the study of human behavior, motivations, and attitudes.

\section{Procedures}

It was not the purpose of the study to generalize to the sampled populations or to the population at large, but rather to purposively seek out participants who would likely identify themselves as theistic, and who might be willing to share their experiences with and views about inspiration in science and scholarship. Because the purpose of the study was not to generalize, response rates are not calculated as they are irrelevant to understanding the responses. 


\section{Sample One}

Participants were randomly selected from Brigham Young University’s graduate and undergraduate catalogs. Professors from departments of botany and range science, chemistry and biochemistry, computer science, geology, microbiology, physics and astronomy, zoology, food sciences, counseling psychology, marriage, family and human development, instructional psychology, philosophy, psychology, school of social work, and sociology were the target population. Professors from undergraduate and graduate school catalogs were randomly sampled. Due to the small number of female science professors (forty-four), surveys were sent to all female natural and behavioral science professors from the above mentioned departments.

All male professors from these departments were placed in a "hat" and randomly selected. One-hundred and sixteen male science professors were selected and sent surveys. Two follow up letters were sent to increase participation. The first follow up letter encouraged participants to either complete or return the survey that they were sent or complete an online survey. The final follow up letter encouraged participants to either return the survey that they were sent initially, complete an online survey, or complete the condensed survey included in the follow up letter. This survey included only the first question from the original survey (see Appendix B).

This sample was comprised of sixty-five professors of natural and behavioral science at Brigham Young University. Not all participants completed all of the questions in the demographic portion of the survey, but from those who did we noted sixteen female and thirty-one male respondents. The average age of participants was 46 . Participants included nine professors of biology, four professors of chemistry, two 
professors of computer science, eight professors of counseling psychology and special education, two professors of family, life, and home economics; one professor of geology, two professors of marriage and family therapy, two professors of nutrition, dietetics, and food science; one professor of philosophy, four professors of physics and astronomy; one professor of psychology of neuroscience, two professors of psychology, three professors of social work, and four professors of sociology.

Sample Two

Participants were randomly sampled from a membership roster of the American Psychological Association (APA) Division 36 (Psychology of Religion) using a random table of numbers. Participants were sent a cover letter and paper surveys along with a website address for completing an online survey. To increase participation, a follow up letter was sent encouraging participants to either complete and return the paper survey or complete an online survey.

The second sample consisted of eighty-five members of Division 36 of the American Psychological Association. Participants were randomly selected from Division 36's membership roster. Not all participants completed all of the questions in the demographic portion of the survey, but it was noted that there were fifty male participants and twenty-four female participants who did complete the entire survey. The average age of participants was 54. Sixty-nine of the participants listed their degree as Ph.D., five EdD., two MS, two PsyD. and five M. of Divinity. Participants included Roman Catholics, Baptists, Presbyterians, Jews, Methodists, Protestants, Christians, Episcopalians, Seven Day Adventists, Unitarians, Atheists, Disciples of Christ, Latterday Saints, Buddhists, and Quakers. 


\section{Sample Three}

Participants were randomly selected from the mailing list of a monthly periodical devoted to the interface of science and religion with a national and international readership. One thousand participants were selected by the periodical's automated random selection process. Participants were sent a condensed cover letter as well as a web site address for completing an online survey.

The third sample was comprised of 300 male and female scientists and helping professionals. Once again, not all participants filled out all of the questions in the demographic portion of the survey, but from those who did we noted 142 male participants and 105 female participants. The average age of participants was 57. Fortyfour of the participants listed their degree as Ph.D., 5 EdD., 13 MD,1 PsyD., 41 MA, 25 MS, 4 LCSW, and 25 degrees in Divinity/ Theology. Participants included Roman Catholics, Baptists, Presbyterians, Jews, Methodists, Protestants, Christians, Episcopalians, Seven Day Adventists, Unitarians, Atheists, Disciples of Christ, Latterday Saints, Quakers, Hindus, Taoists, and Buddhists.

\section{Measure}

The principle investigator developed the questionnaire in collaboration with the dissertation chair, who has scholarly interests in the relationship between science, psychotherapy, and spirituality. The survey consisted of the following questions: 1a. Do you believe that God inspires scientists and researchers in their research and scholarship? 1b. Do you believe God may inspire psychotherapists as they work with their clients? 2a. Have you ever personally felt God's inspiration in your scholarship efforts and/or scientific discoveries? 2b. Have you ever personally felt God's inspiration in your 
psychotherapy work? 3a. Could you please describe an occasion when you have experienced inspiration in your scholarship or scientific endeavors? 3b. Could you please describe an occasion when you have experienced God's inspiration in your therapy work? 4a. What, if anything, do you believe scientists and scholars can do to qualify for and receive inspiration? 4b. What, if anything, do you believe psychotherapists can do to qualify for and receive inspiration from God? 5. Do you have any other thoughts about the role of inspiration in science and psychotherapy that you would like to share? The surveys sent to the first sample did not include a part B for any of the questions. The surveys sent to participants in the third sample had the word profession inserted in place of psychotherapy to include other types of helping professionals such as physicians, clergy, and educators. Participants were able to choose between filling out a paper copy of the survey and going online to complete it. Only the data from part A of the survey will be shared in this study as this study focuses on the role of inspiration in scholarship and science and not on its role in psychotherapy. The data from part B was collected for a future study.

\section{Data Analysis}

The purpose of the data analysis was to describe the content of the participants' responses. Rather than using traditional content analysis which has been used quantitatively, the principles of grounded theory were used to inform category identification. Survey transcripts were analyzed based upon many of the principles and methods of grounded theory. The grounded theory approach consists of interplay between the data and the researcher in which the researcher immerses him/herself into the data generating emergent themes (Berg, 2004; Henwood \& Pidgeon, 2003; Pidgeon, 1996; 
Pidgeon \& Henwood, 1996). Through the constant comparison method of inquiry researchers sift and compare elements within the data in a creative, dynamic way, leaving neither the data nor the researcher unchanged (Pidgeon, 1996; Guba \& Lincoln, 1985). Through this comparing and sifting process, themes emerge and are explored and understood within the context of the question and through the comparison of themes within and between responses. Theory is generated and refined through interaction with the data. It is assumed that the data is flexible as it is filtered and understood through the lens of the researcher.

In contrast to reliability and validity in quantitative research, trustworthiness, goodness of fit, and audit trails confirm the strength of the analysis in grounded theory research. Trustworthiness is established through externalization of the process. Each step is noted through category descriptions, theoretical memos, and other transcriptions. Trustworthiness is also established through dialogue between coders. The subjectivity of researchers is balanced with the requirement of goodness of fit (Burk, 2005; Pidgeon \& Henwood, 1996; Strauss \& Corbin, 1990).

In many ways grounded theory is a good fit methodologically for the nature of the present study. The grounded theory method is useful for exploring under-theorized areas of investigation such as inspiration in science in which little data exists to generate or confirm hypotheses (Burk, 2005; Pidgeon, 1996). In addition, grounded theory is open to broader conceptions of science both in the topics that are open to investigation as well as in the methods it employs (Pidgeon, 1996), which makes it well suited for a study about the possible role of inspiration in science. 
There are aspects of grounded theory that do not fit the purposes nor nature of the present study, including using grounded theory: (a) to generate theories (b) to produce moderate as opposed to thin descriptives based on "rich" data (such as interview transcripts), (c) to integrate multiple sources of data (observation, interview, reports, records, etc.), and/or (d) for iterative data analysis (e.g. collecting data then developing tentative aspects of the theory then collecting additional data). Despite the aspects of grounded theory that are not relevant to our study, the principle investigator and dissertation chair felt the other aspects of grounded theory mentioned in the preceding paragraphs justified the use of grounded theory for the generation of themes.

Traditionally grounded theory methodology also includes axial, thematic, and theoretical analyses which were not used in the present study.

Survey responses were converted to an electronic format to allow for ease of memo writing, exchange of data between participating researchers, and manipulation of text. Researchers were trained in and adhered to the following guidelines of data analysis to help ensure trustworthiness in the generation and coding of themes. A research team consisting of four undergraduate students, the dissertation chair, and the principle investigator divided up transcripts and found initial themes. Then the research team met together to discuss, confirm, and reconsider themes. A "devil's advocate" was assigned to emphasize disconfirming responses and to challenge preconceptions that could influence the analysis of the data and the conclusions formulated. The assigned "devil's advocate" helped the research team avoid "group think" and to consider fresh ways of viewing the data. 
Following the meetings that included the principle investigator and the dissertation chair, the four undergraduate research team members met with the designated undergraduate research team leader to consider themes further. Meeting without the principle investigator and dissertation chair helped balance the influence of the perspectives of the principle investigator and chair. To identify themes, the research team used the five steps (or criteria) for thematic reduction of text offered by Strauss \& Corbin (1990):

(1) Identify a main idea or a central category

(2) Look for subordinate categories

(3) Categories often need to be differentiated or linked with each other;

(4) Examine hypothetical relations among sub-categories as well as between these categories and the main idea by comparing text segments

(5) Noted discrepancies, for instance, inconsistent categories, stimulate further cycles of analysis.

The research team continued to collapse, re-label, and split categories until the data was saturated (no longer contributing further insight). After identifying and collapsing themes, the text was broken down into its smallest components of meaningful and independent thought, and each segment was assigned a theme/category (Erlandson, Harris, Skipper, \& Allen, 1993). The data base was set up with responses listed below and themes listed in a pull down tab to the right of each of the coding spaces. Underneath the coding spaces was a space for coders to insert memos justifying some of their responses and explaining their thoughts throughout the coding process. 
Undergraduate research team members served as first and second coders of the data and made memos explaining the thematic label they attached to a meaning segment. After the data was coded twice by undergraduate researchers, the principle investigator and dissertation chair served as final coders. The final coders coded the data independently and met to discuss and reconcile discrepancies in coding. They also discussed links between categories consistent with theoretical relevance (Pidgeon \& Henwood, 1996).

Following this stage of coding, the principle investigator reviewed all of the responses in light of the research questions and collapsed and relabeled themes. She kept an audit trail documenting her justifications for themes collapsed or relabeled. The principle investigator then looked at each theme again to select themes that could serve as representative quotes for the results section of the study. She then went back to these selected responses and viewed them in light of the respondent. She refined her selection to include the themes that best represented the theme being discussed and the overall study. Explicit searches for disconfirming or contradictory cases in the survey responses were also conducted. These cases were carefully considered throughout the analysis and reporting stages of the study.

Themes were analyzed for both their manifest and latent content so overall impressions could be shared as well as manifest themes. Manifest content is the explicit groups of words found in the transcriptions. Latent content refers to the underlying meaning found from comparing themes, interconnecting themes, and conceptualize the responses as a whole as opposed to its parts. Themes were shared in a narrative fashion as this type of reporting is a good fit for the nature of the questions that were asked. The 
investigators were more interested in gaining insights into how something (e.g. inspiration) is experienced as opposed to the frequency with which it was reported.

Following this stage of data analysis, a $\mathrm{PhD}$ level researcher from a major research university from the eastern United States whose religious background was different (Reformed Jewish) than that of the principal and co-investigators served as an outside auditor. The outside auditor examined the survey responses, the coding decisions, and the descriptions of the themes with the supporting quotes that emerged from the data analysis. The outside auditor verified that the coding decisions and themes were consistent with the survey responses and that the principal investigator had portrayed the participants' responses in an accurate and trustworthy manner. On December 20, 2006, the outside auditor sent the following email confirming her belief that the participants' responses had been portrayed accurately:

You had asked me specifically to review or "audit" your application of grounded theory, specifically coding and development of themes. Every theme that you distilled seems well supported. You work was methodical and meticulous-- an enormous task. In your write-up you clearly lay out the themes true to their original presentation in raw data; an excellent execution of grounded theory. Your dissertation is truly fascinating, and a landmark contribution to the literature. As a fellow scientist, thank you, for making a major contribution to the field. 


\section{Results}

The procedures described above were used to analyze responses to the following areas of inquiry: (a) Could you please describe an occasion when you have experienced inspiration in your scholarship or scientific endeavors; ( b) What, if anything, do you believe scientists and scholars can do to qualify for and receive inspiration; and (c) Do you have any other thoughts about the role of inspiration in science that you would like to share? Results of the analyses with these three areas of inquiry are highlighted separately in this section and outlined in the tables below.

\section{Experiences with Inspiration}

The first major research focus was to learn how the participants in this study experience inspiration in their scientific and scholarship endeavors. In response to the question, Could you please describe an occasion when you have experienced inspiration in your scholarship or scientific endeavors, participants responded by describing (a) the

areas in which they felt inspired, (b) how they experienced inspiration, and (c) the means of receiving the inspiration. Each of these themes is detailed below. Most responses consisted of multiple themes, so overlap in the aforementioned areas may exist in some of the quotes, and some quotes may be used more than once to illustrate various themes. Themes are discussed in a narrative fashion with representative quotes and outlined in Table 2 below.

\section{Areas of Inspiration}

Many of the research participants described specific areas that they felt God's inspiration including (a) in their research endeavors, (b) during times of discovery, (c) in 
their academic pursuits, (d) while instructing and assisting others, and (e) during times of struggle or obstacles.

\section{Table 2}

Participants Experiences with Inspiration in Scholarship and Discovery

Areas that respondents felt inspired:
a) in their research endeavors
b) during times of discovery
c) in their academic pursuits
d) while instructing and assisting others
e) during times of struggle or obstacles.

How participants experienced inspiration:
a) receiving insights
b) feeling guided
c) feeling a sense of calling or motivation
d) serendipity
e) going beyond their natural abilities
f) physical or emotional sensations
g) spiritual manifestations
h) as a constant presence

The means of receiving inspiration:
a) prayer
b) reading spiritual or religious literature
c) meditation
d) submitting to God's will
e) altruism
f) nature 
In research endeavors. Those participants who said they experienced inspiration in their research efforts seemed to experience God in several stages of the research process. Some participants said that they felt God's inspiration as they chose an area of career or scholarly focus. They felt guided by God in choosing a career that would be satisfying and they also felt His influence in choosing a course of study to pursue. For instance, a biochemical professor said that he has felt inspired about "whether to pursue a particular course of research — confirmation came that led to a very productive line of research studying brain function and behavioral expression.” An MD said that he felt inspired in "choosing a field of medicine to go into. I was wanting to become a surgeon, yet had worked in a trauma unit during a war. . I became interested in Internal Medicine, and ended specializing in that." A professor of counseling psychology said, "I believe I have been directed in areas of research as my circumstances have changed and as I have sought a research agenda that would not only impact the field but satisfy me personally." One EdD respondent reported, "The focus of my research has changed as a result of God's inspiration. I had intended to simply study coping mechanisms, and over and over again I would run into articles about healing, spirituality, and intercessory prayer.”

Respondents also reported feeling inspired in choosing their research topic. They felt that God inspired them with ideas for research. For instance a respondent with a $\mathrm{PhD}$ in criminology wrote, "The other day I was reviewing an article for a journal and I was hit with an idea for an article on an unrelated topic." A computer scientist reported, "I felt inspired to choose my current work in biologically inspired computer algorithm." One counseling psychologist stated that she felt inspiration "in trying to organize my line of research, I prayed for clarity to know what to study (I think I was in a 'stupor of 
thought'). A few days later I came up with an additional area and the research ideas keep coming." A respondent from M.I.T said that he has "often felt very strongly directed intuitions for where to find specific information or for guiding me to particular research topics. This recently happened regarding the topic of an address I am giving later this year."

Another stage of research in which respondents described experiencing inspiration is finding resources to help move their research forward. They described feeling inspired to work with certain people as well as feeling inspirational influences in finding literary resources. For instance, an assistant professor of special education related the following:

I was approached by a colleague with an article in very reputable journal the day following my prayer. The volume of the journal had just come out that week. In this journal was a literature review on the topic related to my grant and the 'hook' I needed was within that article.

A professor of computer science related, "As a new professor, I experience inspiration in choosing ... research assistants." A professor of biomedical ethics said, "In one particular instance, it was the more-than-serendipitous discovery of colleagues engaging in the same research." A counseling psychologist reported the following: At each step in this creation process, I've been led to resources and people who can help me take the next step in this project. All of the training and knowledge sets I've gained in the past 20 years have been both 'inspired' and validated in some way. 
Participants also reported feeling God's assistance as they carried out their research projects. They felt that God sustained them in their efforts and assisted them in bringing the "pieces" together. For instance, a clinical psychologist stated, "I was involved in a research project that required handling a variety of logistical challenges. In spite of the difficulties, what we needed to complete the project appeared at just the right time." One respondent with a master's degree in Divinity related, “All of my scholarship and scientific endeavors have been held up in prayer by me and those in my Christian community." Another psychologist reported, "I was given a novel concept and inspiration and energy to pursue it on a couple of occasions that resulted in material that was published." A professor of adult education related the following:

In the creation of some rather complex (many faceted) curriculum, I was having difficulty putting all the pieces together in a coherent, measurable format. I asked the Lord to show me how to integrate the work into a workable, meaningful framework for the literacy students. The very next day, I had the inspiration from the Lord to create several 'complete package' projects - in detail and finality. I still use this format several years later!

Some participants reported feeling inspiration when they took a "break" from the research process and engaged in another activity. They felt God inspiring them during the incubation stage to come up with ideas that they could not find through other scholarly efforts. For instance a marriage and family professor explained the following:

In writing a paper on marriage and family studies, I came to a block in the course of my research and couldn't seem to make a break in the path I was taking; I uttered a very simple prayer for help, went to lunch and came back with some 
what I'd simply call some personally astoundingly fresh perspectives. It truly was inspirational.

A professor of physics wrote, "Often when I'm stuck on something I have a prayer, then walk out somewhere and wait for ideas to come. They often do, in the mountains, in the shower, even in the car." An associate professor of biochemistry reported, "My most insightful thoughts come when I least expect them, typically in the shower, rarely when I'm trying to solve a problem.” Another professor of physics stated, "During the night I received an answer to a problem I had been working on and had been unable to solve." One social scientist said, "I usually find in my work whether it is research activity or therapy when confronting a seemingly impossible solution, if I sleep on it, my problem is usually resolved when I continue my work the following day.” A director of counseling, with a doctorate in counseling psychology with a pastoral emphasis reported, "After a visit to monastery and confession, upon return, a whole article - the basic content of it - came to me in a flash and it took only a few minutes to draft it roughly and then 10-12 hours of follow up work polishing it."

Some respondents reported experiencing inspiration during the data interpretation stage of the research process. For instance, a clinical psychologist stated, "Generally theoretical thinking and interpretation of data can be immersed in the spiritual and so any of several (minor) creative insights can be seen as at least partially divine inspiration." A professor of geology explained that he felt inspired as he found "new perspectives during data synthesis and integration.” One psychologist said that he felt inspired during, "second degree unique synthesis of existing data, and/or comprehension of connection 
within existing data." A biologist stated, "Inspiration comes to me in the form of ideas to explain patterns found in my research."

Finally, participants described experiencing inspiration in the writing stage of their research. Some respondents expressed that God enhances their writing by giving them expressive ideas and organizational flow. For instance, a medical doctor said that he felt inspired in his "writing and expressive work - the way ideas come." One participant who is both a professor of law and a shamanic healer explained that he felt inspired: in scholarship endeavors, I often wait to work until my intuition tells me it is time. When I follow that guidance, I am able to write with ease and the information that comes through is often inspirational and very clear. I also occasionally receive intuitive guidance on ideas and proposals that I take the time to commit to writing when they 'come through.' Often these items don't come to fruition until much later in a project or a relationship with a client, but the information 'informs' all my interactions once I've received it" An MSW reported the following:

I often sit down and write, not knowing what I will say and how I will say it. There are times when the words flow freely and it almost feels as if I am not doing the writing but that the words are coming from outside of me. This outside of me energy is what I call God."

One participant with a $\mathrm{PhD}$ in history and philosophy of science shared the following: I am not a scientist per se but a philosopher of science. I have published several articles on light as it is defined and puzzle over by physicists. I feel that I have 
received inspiration from both sacred and secular sources as I have written these articles.

A respondent with a doctorate in Psychology/Metaphysics related, "My writing o journal articles and books seem written by themselves. They come to me during sleep full-blown, the topic - the chapters."

During times of discovery. Some respondents reported experiencing inspiration in the discovery process. They felt God's influence in solving challenging problems and discovering new solutions. For instance, one chemist wrote, "I thought a structure should be a certain way but could not find evidence for it. I felt impressed to try certain things and then I found the missing structure." A geology professor described his experience with inspiration as, "Direct and specific guidance to go places and look at things not in the plan (oblique discoveries)." A professor of social work said, "With a colleague, formulating a model of gender-sensitive assessment and intervention wherein the principles of 'individuality' and 'sense of community' (commonalities) came together strangely, reflecting God's sense of every person's uniqueness yet our relationship as brothers and sisters." An associate professor of integrative biology with a $\mathrm{PhD}$ in molecular evolution and systematics described the following experience:

During graduate school, I was faced with a life situation that was very trying - a great personal injury. It was during this period, at time of tremendous spiritual insight that I made a discovery that had literally been staring in scientist's faces for nearly 20 years. It was this discovery that has since become the central foundation of my research program. 
A professor of physics reported, "One night I was awake thinking about a research problem while lying in bed. Suddenly I thought of the solution. It was an elegant solution." An MD shared his experience with inspiration, "Last summer this area had severe West Nile outbreak. Started searching and praying for answers. Got an answer that has helped most of my patients chronically ill with West Nile virus." One engineer related the following:

When I worked in aerospace, I was a junior member of a research team in a company that was trying to be the first to develop a specific material. The task was given to the senior research staff members but they were unable to come up with a solution even after two weeks. I was asked and within an hour I had a solution and a prototype for the material they were seeking. I had mentally gone into the void/creation space of the universe with God's light and let my mind float for a couple of minutes, sort of like a meditation. When I came out of the trance, I worked as fast as I could in creating the material they were looking for.

One educational administrator shared the following experience:

When sitting in my kitchen in the late 1980 's, I felt a strong need to design my own professional tool to help people understand the gifts that each brought to others just by being themselves. I already had access to an instrument of assessment that described the behavior of people at work or in the home, depending on the focus a person had when answering the questions. I did design this assessment tool and combined it with the behavioral instrument and went on to give them to several thousand people. I felt happy to bring the positive side of a person's habits of thought to them, because then they could see why some 
behaviors they were expected to perform did or did not match their preferences. This helped people to stop beating themselves up when procrastinating or other resisting behaviors, because they understood that while they were capable of the task, it was not a preferred and natural gift of theirs. It was a learned behavior. I think it is easier to love yourself and love others when negative judgment about what you see yourself or others doing is reduced or eliminated through deeper understanding. The urge to design this instrument came after I prayed for a better way to interact with clients and be less judgmental myself.

In academic pursuits. In addition to experiencing inspiration in the research and discovery processes, some respondents shared their experiences with inspiration in their academic training. As scientists worked toward their future degrees, they felt inspired about where to go to school, what to study, and they felt strengthened and guided in the study process. For instance, a behavioral scientist said, "I was absolutely led to start school again. The window opened up for me and everything fell into place. I know it was God at work." One master's student shared the following:

During some of my writings for my first master's paper at Northeastern University, I felt the guidance of an entity that seemed to be using my mind and hands to write an essay paper on community issues. This took place in 1994. I was amazed at the results because it seemed so unlike my writing style. A respondent with a Masters in Social Work (MSW) explained that "locating an academic environment with faculty who were open to a study on meditation as a dissertation topic makes me feel that the Creator is indeed continuing to inspire me and 
facilitating this work." A professor of mathematics reported, "Course's that I have taken that have proved to be difficult have been made much easier by asking for Divine help." In instructing and assisting others. Several participants described occasions when they felt inspired as they were instructing and assisting others. Some felt God guide them in preparing and presenting information for others; others felt His influence as they counseled with others. For instance, an educational psychologist stated, "In class preparation, I occasionally get an inspiration that involves a better way to present a topic or make a point." A professor of biology related, "I was teaching a class, some of the material was potentially disturbing to the testimonies in the class. I was given a dream on how to handle the material with respect to the class scholastically." A professor of physiology and developmental biology reported, "I have felt more inspired in my interactions with students than in my personal research efforts."

During times of struggle or obstacles. Other respondents described feeling God's influence in overcoming obstacles in their scholarship. Respondents described arriving at a "stuck point" and then feeling God provide a way for them to resolve and move past it. For instance one respondent with a master's degree in counseling stated, "While at an impasse while typing a paper, I sought assistance as I worked. Almost magically within a short time I was able to overcome that stalemate and conclude my efforts successfully." One respondent with a $\mathrm{PhD}$ in nursing stated, "I often find that what I perceived as a logical 'roadblock' simply wasn't there if it was what I was 'supposed' to be doing." One physicist reported, "God is with me at all times. When I have been discouraged, prayer has led me back to the areas requiring further analysis and with good results." A professor of Biblical studies shared the following experience: 
I was struggling over the way forward in a research project, confronted with multiple options and major ambiguity. While in prayer about the matter, an alternative came to my attention in an 'aha moment,' which ultimately led to a major contribution.

A professor of microbiology said shared the following:

There have been many instances when I have been so burdened by the challenges and setbacks associated with scholarship and scientific endeavors that I prayerfully released the struggle to find the solutions to the problems to God and came before him with humility and confessed that I alone could not solve the problems...that I needed to rely on Him. He has never failed me. Doors were opened, resources discovered and solutions provided. It has not always been through inspiration that He has guided me, but His hand was clearly there and His presence clearly felt.

\section{Manifestations of Inspiration}

Several participants shared how they experienced inspiration in their scholarly activities including: (a) receiving insights, (b) feeling guided, (c) feeling a sense of calling or motivation, (d) serendipity, (e) going beyond their natural abilities, (f) physical or emotional sensations, (g) spiritual manifestations, and (h) as a constant presence.

Insights. Many participants described feeling enlightened by God during times of scholarship and research. Inspiration was experienced as a "flash" of insight, a new understanding, a "voice," or connections between ideas. For instance, a scientist of physics related the following: 
It is really hard to give specific instances because my experience has usually been that I will be working on a difficult problem that I just can't get to work properly. Then there will be a 'eureka moment' where some aspect of the problem will suddenly become clear and progress can continue.... It may relate to prior knowledge but the synthesis that results in that moment is something completely new. Often these moments are only recognized in hindsight.

An MD shared the following:

In my family practice I have had sudden insights and occasional diagnoses come to mind. I almost always had to look up the treatment protocols for these diagnoses that I 'received'. Student Dr's that were rotating on my service at the time have been known to ask, 'How did you know that?'

A professor of social work said, "I receive 'downloads'--Clair cognizance--where suddenly I just 'know' or gain new insights into whatever I'm working on. This occurs several times a week. I now expect them."

A respondent with a master's degree in Divinity said the following:

New information appears... New insights seem to emerge from the process of reading and thinking and writing. It's possible that these 'new' insights emerge because of the juxtaposition of my former thoughts and the thoughts of other authors. However, they seem to be original thoughts, more than just combinations of previous thinking. And they demand that I pay attention to a silent depth which allows them to surface, but not necessarily at my bidding.

A professor of chemistry described how feels inspiration is experienced, "I do believe that God 'quickens' our understanding and that all thought is influenced, perhaps 
imperceptibly, by the Holy Spirit.” One social scientist responded that she experiences inspiration as "words ... coming from outside of me. This outside of me energy is what I call God." One counseling psychologist described inspiration as "a voice in my heart, which I interpret as God's inspiration, has encouraged me many times through difficult research and auditing processes." One theologian reported, "When I see a connection between ideas or experiences I hadn't seen before, that inspiration feels like a gift that comes from beyond myself. I call that source God.”

Guidance. Several respondents described experiencing inspiration as a feeling of being guided or led to go in a certain direction in their research or in their career focus and endeavors. For instance, a professor of biology related the following:

When my research findings are not what I expect to find, I feel that God is leading me in another direction--When I have gone in the research direction that I have been inspired to take, I have had much success!

One social worker stated, "I have often been at a cross road in my endeavor and I have felt as if I was being told the correct path to follow." One chemist stated, "God led me to leave my career as a chemist and study to become a science teacher." An occupational therapist reported the following:

I believe that God provided me with the inner desire to find the field that I work in right now, because it is so fulfilling to me, and fits my gifts and abilities ... I believe His hand was guiding and directing me throughout my education to become the person I am, doing the work that I do with my patients everyday. Sense of calling. Some participants experienced inspiration as a sense of calling or motivation. They described feeling "called" to a certain work, or as if God had given 
them the desire to pursue a certain course of scientific endeavor. They also described feeling that God gave them inner strength or motivation in their work. For instance, one psychologist wrote the following:

My very choice of psychology as a profession came from having three students who had consulted with me, as an academic dean, about their programs commit suicide shortly thereafter. I changed from English to Psychology in order to offer emotional, psychological, and spiritual assistance to such persons, for I believed that was what God would have wanted for them. I have also participated in pain management research (TMJ/TMD) and EMDR research because of God's call to keep others from undue physical and emotional suffering, from despair and an inability to live a quality life. I am currently writing a book on managing transference and counter-transference in non-analytic therapy for the reasons given above.

A doctor of ministry stated, "It was through God's intervention that I was guided into the healing ministry." In regards to a certain research project, one psychiatrist reported "I felt inspired to move forward and felt carried forward in the process." Another psychologist reported, "When working on statistics for dissertation - inspiration and motivation to keep going through setback."

Serendipity. Some respondents said that they experienced inspiration in the form of serendipity. Pieces seem to come together in surprising and needed ways to further their work. For instance, a clinical psychologist related the following:

I was involved in a research project that required handling a variety of logistical challenges. In spite of the difficulties, what we needed to complete the project 
appeared at just the right time. I also believe that there is serendipity involved regarding the projects that come my way.

Another clinical psychologist wrote the following:

In this particular occasion, I felt as though a field of study which I rather stumbled upon, was suddenly something empowered by God and it seemed as though he was putting together many circumstances and contacts to progress my work in this area.

An associate professor of internal medicine reported, "Serendipity made it possible to start research in Hyperthermia." A counseling psychologist reported, "As a Jungian psychologist, I believe that synchronicities are from a Divine Hand. I am constantly experiencing an 'inspiration,' followed by a validating synchronicity."

Enhanced abilities. Other respondents described feeling inspiration as a source of added strength to go beyond their natural abilities. They felt that God inspires them by helping to uphold them and enhance them in their efforts. For instance, one participant with a PhD in school psychology related, "I think that the Lord opens various doors/windows so things can get done-He magnifies my meager efforts." A psychologist reported, "I felt I was given a novel concept and inspiration and energy to pursue it on a couple of occasions that resulted in material that was published." A professor of physiology and developmental biology shared the following:

It is my sense that my talents are blessed as I keep the commandments and serve the Lord. When I am living close to the Spirit, my thoughts seem more lucid, and my ability to reason seems more clear. 
An assistant professor of counseling psychology said "I believe ideas come to me as inspiration — that is, ideas beyond my mortal capacity and understanding."

Physical or emotional sensations. A few participants described feeling God inspired them through a physical emotional sensation. They described the emotion or physiological response that accompanies being inspired by God. A professor of law reported recognizing inspiration in the following way:

[I would get] a physical pain or stitch when I had distorted the truth of a matter.

Thrusting out during an in depth interview into new and deeper waters; a sense of God leading, something that has occurred on several significant occasions. I remember once when I was essentially confronted by the Holy Spirit that my reporting was superficial and written to hurry up and get on to the next matter. A gerontologist related the following: In helping dying and elderly residents face the final transitions in their lives, I often have found a calm intuitive self presence that can only be described as God inspired. This was especially verified when working with a late stage Alzheimer resident, who was in the active stages of dying. I felt that my presence and the presence of God through me helped this gentleman come to a place of peace before he died.

A clinical psychologist described inspiration in the following way: I guess my experience was characterized by surprise, and a sense of warmth, which I felt as though sprung from God's personal care for me. I think the prevailing emotion that characterized this "inspiration" was joy, and a sense of purpose. 
Spiritual manifestations. Some participants said that God inspired them through spiritual manifestations. For instance a professor of integrative biology was "given a dream on how to handle the material with respect to the class scholastically." One counselor reported, "When I was learning to do cognitive therapy, I had an experience as if God was telling me: 'Physician, heal thyself.' I began applying the ideas to my own life, and relationships got much better." A clinical social worker said, "When reading inspired spiritual books and articles I often feel that the written word speaks directly to me. I often get the answer to just what is troubling me from these sources exactly when I need to know." A mechanical engineer related the following experience:

When called into a meeting (cold) to discuss the feasibility of ash separation on that fine of a particle level, before even having a chance to analytically consider the idea, a 'picture' entered my mind to do just that. A patent ultimately followed. Frequently, a picture does not immediately arise; rather a sustained openness allows an inner discovery to bubble up to awareness that can be applied. As if an inner non-directed sorting between 'problem' and 'answer' must be allowed until correctly pairing." Another engineer reported, "I have also felt the protection of angels when I needed them.

One respondent with a master's in theology related the following:

During some of my writings for my first master's paper at Northeastern University, I felt the guidance of an entity that seemed to be using my mind and hands to write an essay paper on community issues. This took place in 1994. I was amazed at the results because it seemed so unlike my writing style.

A professor of social work shared the following: 
In the development of a manual for helping families, the lessons were revealed and typed as directed. No changes have been made or suggested despite several pre-post tests and constant evaluative feedback.

Constant presence. Several participants said that they felt God's inspiration in their life constantly. They describe experiencing God's influence as a regular part of their research as opposed to describing rare, extraordinary experiences. For instance, an associate professor of psychology said, "I believe this occurs constantly, not in rare moments that have a heightened quality of animation or external influence." A counseling psychologist stated the following:

I think that God inspires for the sake of redemptive purposes. At times I feel wonderfully creative, empowered and aware as I represent God. However, I can't call this inspiration as sometimes I feel tired, bitter or distracted - is God absent? No. God is present and active in spite of my sense of inspiration. I submit to who I am called to be - as made clear through Holy Spirit.

An assistant professor of chemistry wrote, "I can't think of any specific occasion; my research successes have been the result of long hours of persistence and hard work, and I believe that a certain level of inspiration has been present throughout.” A biology professor reported, "There have been numerous occasions. Everything I have accomplished has been the result of numerous, daily inspirational experiences." A respondent with an Ed.D. stated, "I believe it happens quite frequently, in ways that I often fail to recognize as inspiration. Certainly when I am stuck or confused in my research, I am not being led by the Spirit." An educational psychologist said, "I am 
always, at least at some level, conscious of God's involvement/participation in life's activities and endeavors."

\section{Means of Receiving the Inspiration}

In response to the question, Could you please describe an occasion when you have experienced inspiration in your scholarship or scientific endeavors, some participants described the means through which they experienced God's influence. Respondents experience inspiration through (a) prayer, (b) reading spiritual or religious literature, (c) meditation, (d) altruism, (e) submitting to God's will, and (f) nature. Prayer. Several participants said that they received inspiration as a result of praying or asking God for help. For instance, an assistant professor of school psychology related the following:

I believe my prayers concerning finding participants for my dissertation [were answered]. I prayed before my dissertation proposal and final defense so that I could communicate clearly and my committee would be supportive and that I would understand their questions. It went well.

A professor of integrative biology stated: "The largest research contract I received came from an idea I was praying about during a 5 mile run—intensely praying for inspiration has saved my teaching and research time and time again." A respondent with a master's of Divinity in Christian Theology wrote the following:

As a seminary student studying for my M. Div. and ordination as a Minister of Word and Sacrament, I found that after praying and asking for insight into a particular portion of the study I was undertaking, and the application to my internship context, I was able to understand more clearly the writings, ask more 
clear and probing questions and find better ways to express new understandings. A participant with a $\mathrm{PhD}$ in education said, "In moments of being unable to resolve a scholarly problem, having prayed for assistance, I have actually been given it and been carried into an 'altered state' to successful conclusion. Additionally, I once completely aced a seriously difficult graduate level physics exam simply after praying - and I had not studied! The grace of God somehow was bestowed in both cases here.

Spiritual or religious literature. Other participants said that they experienced inspiration as a result of reading sacred texts or spiritual literature. They suggested that reading religious texts enhanced their thinking and helped them find direction for their research projects. For instance a clinical psychologist reported the following:

In the process of studying Buddhism, reading such books as the Tibetan Book of Living and Dying (Sogyal Rinpoche) and No Death, No Fear (Thich Nhat Hanh) and practicing meditation, I have thought more deeply about Kharma and rebirth and feel inspired to write a book about death, enlightenment, and resurrection. An engineer related the following:

[I] had a multi-year project to review, redirect, stop or start about $100 \mathrm{R} \& D$ projects. It involved a lot of deep questioning and cooperation/confrontation with vested interests. To do this, I had to live in Washington, apart from my family. I fell into a habit of Bible-reading, meditation about that and my purposes, and prayer that had a considerable influence on how I proceeded ... sometimes recognizing possibilities or restraining my impulses.

A psychologist shared the following: 
For the past five years there has been an integration of psychology and spirituality for me. My academic training was in psychology. After five years of spiritual direction and reading in the area of spirituality, I will now be entering a two year program in spiritual direction. God's inspiration has helped me see how I can integrate both psychology and spirituality in my academic endeavors and professional practice.

Meditation. Some respondents said that they experienced inspiration through meditating. They suggested that meditation helps invite God's influence into their scholarly endeavors. For instance a professor of mathematics related, "I was initiated into kriya yoga in 1973 and use meditative practices to get into touch with the consciousness of elementary particles." A respondent with an EdD in social science education stated, "After contemplating and thinking about questions and issues, I often receive answers or intuitions when meditating." One social worker related the following:

My long-time attraction to spirituality and the inspiration to bring meditation and the experience of the interior Silence to the profession of social work, coupled with locating an academic environment with faculty who were open to a study on meditation as a dissertation topic makes me feel that the Creator is indeed continuing to inspire me and facilitating this work.

A clinical psychologist shared the following:

I spent one hour daily meditating on the meaning of religious vows and then wrote conferences on 'treasures in Easthen Vessilo,' my graduate students took the manuscripts to a publisher since they were inspired by the talks. A book resulted in 13 languages (translated). Meditation had led to expression of spiritual 
experience and understanding — which led to publication through inspired students."

Altruism. Others described experiencing inspiration consequent to their altruistic motives. They felt God inspired them to help others and as a result of a desire to help others. For instance a professor and director of community service related:

[I felt inspiration] in working with community foundations in the first ever partnership to establish a statewide technical assistance center that could better reach new and struggling nonprofits run by low resourced individuals in poverty stricken rural communities across the state."

One respondent with a PhD in pastoral counseling said, "When I have the freedom to be present to a person without too much of my own ego, I perceive that as God." A professor of sociology reported the following:

One time the Provost at my university asked me if a particular study could be done. He did not see any way to do it. Neither did I. The study would be very valuable to the university and its sponsoring church. As I walked on campus one day the insight came how to conduct this study. A memo to the Provost the next day elicited a phone call from him. The study was conducted and I feel it made a significant contribution to the university and church.

A professor of integrative biology shared the following:

I wrote a proposal for a 3-year research grant as a new assistant professor. It was my first proposal for major funding. I wondered how I could be professionally competitive with colleagues who devoted more time to their professions while I was attending and serving in my church during evenings and weekends. Still I 
worked hard in my profession during the week. As I prepared the proposal, thoughts and organizational ideas came to me and I feel the Lord blessed me because I was doing my best to serve him and work in my profession. The research was funded. During the project I felt a need to redirect major funds toward certain aspects of the project. I believe that was also inspiration. That redirection really improved the output of the project and laid the groundwork for a subsequent major research focus for my career.

One respondent with an EdD in psychology and a MD wrote, "I have written and published personal case histories so that God can use that material to help others.” .

Submission to God's will. Some participants felt that they received inspiration by having faith in God and obeying His will. They said that having faith in God allowed them to see His influence in the world and also to have courage to follow Him where he guided them to go. For instance, one chemist wrote the following:

I believe in God. I believe God is/was/will be the origin of our 'natural' universe. I believe God is/was the origin of the spark of life that became me. My choice of 'chemistry' and science as my profession was driven by that part of myself that is, uniquely, me. Since God and myself are the only ones who have true access to that part of me, my early curiosity over light, colors, rainbows, fire, and fireworks probably was, at the least, related to God's handiwork. My choices of spectroscopy, photoluminescence, physical chemistry, and such, for special study, were, also, similarly related to God's handiwork.

A counseling psychologist related the following: 
My very choice of psychology as a profession came from having three students who had consulted with me, as an academic dean about their programs commit suicide shortly thereafter. I changed from English to Psychology in order to offer emotional, psychological, and spiritual assistance to such persons, for I believed that was what God would have wanted for them.

An analytical engineer wrote the following:

I have always begun and ended my days with a prayer. In situations when I was under a high pressure due to short deadline, situations that my colleagues considered a highly stressful, such as writing a technical paper or trying to analyze, understand and explain a rather difficult problem. I have never panicked in a highly stressful and critical moments. I have always had an assurance that all will be fine at the end. I believe that this assurance is always there if we are willing to accept God's will.”

Nature. A few respondents also replied that they felt God through nature. This theme emerged as a sense of being inspired about God through nature. A chemist stated, "I have always had a fascination and admiration for all of God's handiwork in his creation." An experimental physicist said that he experienced inspiration "when I realized that I as an experimental physicist, I was recognizing God as the creator of everything that exists." One respondent with a master's in Divinity said that "as a student, the beauty and intricacy and organization of the natural order inspired feelings of awe and wonder in me at the interconnection of everything." 


\section{Preparation for Inspiration}

In response to the question, What, if anything, do you believe scientists and scholars can do to qualify for and receive inspiration, participants shared suggestions about how scientists may be prepared to receive inspiration in their scholarly endeavors. In addition to specific suggestions for preparations, some participants responded to the terminology of the question by clarifying their views about the nature and availability of inspiration. Suggestions emerged as the following themes: (a) be open to the possibility of God's inspiration, (b) seek for and/or pray for inspiration, (c) be humble, (d) have gratitude or a sense of awe, (e) live a virtuous life, (f) have a relationship with God, (g) have altruistic motives, (h) do the work, (i) dialogue with others, (j) read spiritual literature or sacred texts, (k) meditate, (l) focus on the "heart"/soul, and (m) no one qualifies to receive inspiration. Themes are discussed in a narrative fashion with representative quotes as outlined in Table 3 below.

Be Open to the Possibility of God's Inspiration

Several respondents suggested that scientists and scholars be open to the possibility that God may inspire them in their work. This included a willingness to look beyond the naturalistic methods of gaining knowledge to the possibility of God's guidance in their quest for understanding, as well as having faith in a divine influence. For instance, one clinical psychologist suggested that scientists cultivate "1. Personal faith and belief in God. 2. Openness to God's leading in these domains specifically - not just in personal affairs..." A sociologist suggested the following:

I believe that people must first of all, be open to accepting the idea that we can be divinely guided in our work. When we are open to possibilities beyond our own 
Table 3

Participants' Suggestions for Preparing to Receive Inspiration in Scholarship and Discovery

What scientists and scholars can do to receive inspiration:

a) be open to the possibility of God's inspiration

b) seek for and/or pray for inspiration

c) be humble

d) have gratitude or a sense of awe

e) live a virtuous life

f) have a relationship with God

g) have altruistic motives

h) do the work

i) dialogue with others

j) read spiritual literature or sacred texts

k) meditate

1) focus on the "heart"/soul

m) no one qualifies to receive inspiration

personal limits, it is possible to attune to a frequency of unlimited creative solutions, ideas and inspirations that are meant for us to experience.

A respondent with a master's degree in theology and education said, 
I find that when I open myself to possibilities and not stay in the box of traditional decision making that inspiration comes more quickly and easily. If one of the things God is the being we meet at the limits, then going to the limits opens the possibility to move into the presence of God.

A clinical psychologist said, "Becoming more mindful and more open-minded, less dogmatic and narrow minded." Another psychologist said the following:

I think scientists who see the physical world from a spiritual perspective are open and will receive inspiration from God. Acknowledging the wonder of the universe and the grace filled presence of God as Creator (continually creating) opens the scientist to God's presence.

One respondent with a $\mathrm{PhD}$ in social work and psychology recommended that scientists "examine their own spirituality and ... consider the possibility that there is a higher power or a source which can be incorporated into their endeavors, whether it is research, teaching or clinical services." A respondent with a master's degree in psychology said, "Faith involves believing in things that can't be seen or fully comprehended by the human brain alone and scientists may have a hard time with that." Another psychologist suggested "openness to God's leading in these domains specifically - not just in personal affairs" helped invite inspiration.

\section{Seek and/or Pray for Inspiration}

Other participants encouraged scientists and scholars to pray for inspiration in their work. They felt that praying for God's guidance could help them with their experiments and specific research problems. An assistant professor of integrative biology suggested, "Pray for guidance in research program, keep communication open - pray 
often, I pray over the quality of the research, I pray that experiments will succeed, etc." A professor of biochemistry recommended that scientists "seek inspiration for answers to specific questions or needs." A member of the clergy stated the following:

I believe that prayer will help to reveal new ideas and bring in new information for this age. With the expertise that the scientists and scholars have been given, I believe that prayer will unlock mental energy that has never been used before and could possibly find cures and hidden knowledge that is ready to be revealed in this time. The power of prayer is a mystery in any field of endeavor.

\section{Be Humble}

Some respondents suggested that scientists and researchers may be more likely to receive inspiration in their work if they develop an attitude of humility in their scholarly endeavors. Humility included recognizing the need for and having an awareness of a divine source of assistance in scientific pursuits. For instance a computer scientist recommended that scientists practice "humility - acknowledge help given." A professor of integrative biology encouraged scientists to "reduce their self-centered pride. Live their lives on the Lord's terms--not on their own." A professor of social work said that scientists should "be teachable. Be humble. Acknowledge the source." Another computer scientist suggested that scientists "be humble about God's omniscience." A respondent with a $\mathrm{PhD}$ in psychology recommended that scientists "have the humility to recognize the limits of human ability." A professor of communication stated, "Remain humble in how we hold our theories of the universe, reflect on the paradoxical nature of human experience--surrender ourselves to the possibility of grace." 


\section{Have Gratitude or Sense of Awe}

Similar to humility, a number of participants recommended that scientists develop the attribute of gratitude. This recommendation included having a sense of "awe" and thankfulness for God's hand in their work and in the world. For instance, one psychiatrist said that "an attitude of reverence towards creation and higher power" can help scientists receive inspiration in their scholarly pursuits. An industrial scientist stated, "Awareness of, respect for, and enjoyment of the gifts God has given, uniquely, to each of us would (should) be enough to keep us on a good path." A clinical psychologist said, "Cultivate within oneself the classical view of scientists toward God, i.e. that the wonders of scientific discovery lead one to acknowledge and express gratitude for the wonderful world that God has made."

\section{Live a Virtuous Life}

Other participants said that they felt scientists could prepare to receive inspiration in their work by living a virtuous life. Their responses included keeping the commandments and obeying God and living honest and good lives. For instance, a professor in an integrative biology department suggested that scientists "live deeply and committedly to the gospel." One psychologist said that scientists can prepare to receive inspiration "by being authentically true to themselves, serious about their work and open to possibilities." A respondent with a PhD in theology suggested that scientists "live righteously -worthy to receive wisdom of the Spirit.” A professor of psychology recommended that scientists should cultivate a "good heart—and an ability to access grace" to help them receive inspiration in their work. A professor of entomology and zoology said, "I believe God is most likely to lend inspiration to those who ask (pray) and 
those who live in such a way as to optimize communication with Him (obedience, times of personal reflection, etc.)."

\section{Have a Relationship with God}

Some participants recommended that scientists develop and nurture a relationship with God to help them prepare to receive inspiration. For instance a licensed clinical social worker said, "One 'works' at their relationship with God, and at their work with intention and patience. Having a spiritual practice, working on building a relationship and 'walking with God' is important. However, one must be open, and be able to differentiate between their own ideas, and those insights that God shares with them. Also, one needs to ask for God's help and extend an invitation that they work together." An MD said, "Whatever we receive from God comes from an ongoing relationship that already exists. I don't know whether the relationship could be cultivated for the purposes we might desire. I do believe that all creativity that is beneficial is a gift of God. He bestows it on His timetable and purpose, not ours."

\section{Have Altruistic Motives}

Other respondents suggested that scientists pursue their scientific endeavors with altruistic motives. They suggested that when scientists conduct their scholarship with the desire to bless others they may be more likely to receive divine assistance in their work than if they are doing the work solely for their own benefit. For instance, a professor of philosophy of science encouraged scientists to "work on your project but take time to help and comfort others. Then inspiration will be forthcoming." A professor of counseling psychology stated, "I think the primary condition, if there is any, is to be a genuine seeker of truth with the desire to share these truths to the benefit of humankind." 
A professor of psychology suggested that in order for scientists to experience inspiration they should have a "desperate need, pleading — sincere, deep effort and wish to ameliorate suffering of others." A marriage and family therapy professor recommended that scientists have "an eye single to the glory of God and service to others. This is a real key to opening heaven's windows."

\section{Do the Work}

Several participants suggested that doing the rigorous work of research was a necessary stage in receiving inspiration in their work. This included working hard on the question at hand as well as developing a curious, inquisitive nature. For instance, an entomologist said that along with other things, scientists should "Work like everything depends on you." A professor of integrative biology said, "work as hard as possible on the question at hand." A professor of psychology and special education suggested that scientists may be more likely to receive inspiration when they are "doing their part of the work, e.g., reading, discussing ideas with other researchers, trying to solve a problem on their own first, their seeking divine assistance (and being willing to continue working hard) to come up with solutions." A neuroscientist said, "Consider all of the significant breakthroughs for the benefit of mankind by those paying the price of preparation and going with a prompting received as alternatives are examined." A biology professor said, "I think this is largely a function of one's curiosity, motivation, and self-discipline. Without these things, I don't see how one can expect to receive inspiration, regardless of what other courses of action one." A geology professor recommended that scientists "put in the work and exhaust all possible tests and observation - let go of it for a season, 
providing time for incubation and the subconscious to activate - focus when new ideas and connections begin to flow."

\section{Engage in Dialogue with Others}

A few respondents suggested that scientists may be more inclined to receive inspiration as they engaged in dialogue with others. They felt that by discoursing with other scientists they may be able to find solutions and that God may speak through others. For instance, a philosopher of science suggested that scientists recommended the following:

Be open to the environment around them. What are the voices of nature saying to them? What do other reliable scientists and scholars have to offer? These multiple voices, whether they agree with them or not, are ways that they can be inspired by God.

A counseling psychologist said that scientists may be able receive inspiration more readily by "discussing ideas with other researchers." A respondent with a BS in psychology said that scientists should "welcome other scientists/religious people's ideas, believing that God can speak through each person in [their] life."

\section{Read Spiritual Literature or Sacred Texts}

Some respondents encouraged scientists to read spiritual literature in order to prepare themselves to receive inspiration in their scientific pursuits. This included reading the Bible as well as other spiritual literature. For instance, a psychologist suggested that scientists "read the scriptures to know the mind of God." A professor of special education said, "Study both secular and spiritual sources. Ponder what I've read." A clinical psychologist encouraged scientists to "study or research spiritual topics." A 
professor of community relations encouraged scholars to have an "active communication with God through prayer and Bible reading so that when He speaks you can sort His communication out from your own leanings or on some occasions to trust your own leanings as not self serving."

\section{Meditate}

Other respondents recommended that scientists practice meditating to help them prepare to receive divine guidance in their work. The suggestion of meditation was often, but not always, stated in conjunction with prayer. For instance, a clinical psychologist said, "Practice meditation and/or centering prayer, becoming more mindful and more open-minded, less dogmatic and narrow minded." A rabbi recommended the following:

Meditative Prayer to open up those channels that enables us to receive Divine Inspiration .... By consciously seeking to perceive the Presence of the divine in the fabric of the particular scientific, historical or product of Human ingenuity we are researching. We thereby create a connection between our studies and the transcendent. We create a 'virtual neural pathway' between our minds and the Divine Intelligence.”

A speech pathologist said the following:

Prayer and meditation help a person to focus and enter into deep thought about ideas and problems. Using steps in the creative process moving from idea to imagination, understanding, and judgment culminating perfection or near perfection in the finished product, a scientist and scholar will know that the finished work was inspired by God.

A psychiatrist said that scientists should, "Meditate and study with an open mind." 


\section{Focus on the "Heart"/Soul}

Several participants said that as scientists focused on their "heart" or soul they may be more able to prepare for and recognize inspiration in their work. This included getting in touch with an inner, intuitive side of oneself as well as not relying solely on empirical ways of knowing. An integral psychologist said that scientists should "keep their analytical, logical minds the heck out of the way." An MD said the following: It is necessary to systematically transform oneself through sustained spiritual practice, whether it be selfless work, learning to love unconditionally, seeking to know who one truly is, or striving to see the whole universe as a manifestation of the divine. We cannot arrive at inspiration with our discursive minds alone. We have to go to deeper levels of who we are, and that can be attained only through sustained and systematic effort. All religious traditions contain disciplines to that end, though they might not express them in quite this language.

A participant with an MS in special education stated, "Develop emotional intelligence." A transpersonal psychologist suggested the following:

Cultivate awareness of the Spirit Within. Work to heal any negative emotional issues and arrogance/bias that would get in the way of hearing and accessing the wisdom and creativity already there in full inside of us. Sit in silence a little while every day. Learn to feel emotions (as repressed emotions get in the way of the voice).

A social psychologist said that scientists should "give credence to their unexpected thoughts. Don't insist on always having 'touch it or measure it' proof." 


\section{Receive Inspiration as a Gift}

Along with the suggestions mentioned above, many respondents said that they believe no one "qualifies" to receive inspiration, but rather it is a gift that all scientists may receive. Some responses seemed to reflect a general objection to the term "qualify"

as stated in the question. Other responses that fell under this category suggested that there were no qualifications needed for inspiration; however, they went on to list things that scientists could do to encourage inspiration in their work. Other responses reflected a belief in "grace" concerning receiving inspiration in scientific pursuits. For instance, a clinical psychologist stated, "I believe that divine inspiration may happen to any scientist regardless of their belief in God." A physicist said, "I'm not sure how personal worthiness influences scientific inspiration. I know of rather immoral men who were world-famous scientists." A professor of physiology related the following:

I think many discoveries of importance may be inspired without the person knowing it or doing anything to prepare. I believe that righteous living better helps on to be receptive to the spirit, but I have not observed any evidence to convince me of a correlation between personal righteousness and important discoveries. In many cases, I think the Lord simply cares more about how we treat each other and grow spiritually than he cares about technological advances. As needed, the technology comes, and it does not seem to matter whether it comes through believers or not.

A professor of physics said the following:

I feel that any scientist or scholar may receive inspiration when appropriate. [Religious scientists and scholars] in no respect have a monopoly on inspiration. 
In my opinion, when the Lord needs some temporal progress to help the spiritual work go forward, He will give the necessary guidance to whoever is in a position to help that particular development move forward. It is important that we are 'good within the limits of our knowledge' in order to be worthy to receive this inspiration. And since most people are basically good within the limits of the knowledge they have, they would be worthy of guidance when it is appropriate and needed.

A clinical psychologist stated, "I don't know that there is any human being that doesn't receive inspiration from God. To be aware of it or attribute it properly, though, it helps to establish a relationship with God." Another clinical psychologist said, "We can't qualify for inspiration. It is a free gift given by God. We can, however, pray for it and live our lives in a virtuous and balanced way - to be available to receive (hear) it when it is given." An MD wrote the following:

Whatever we receive from God comes from an ongoing relationship that already exists. I don't know whether the relationship could be cultivated for the purposes we might desire. I do believe that all creativity that is beneficial is a gift of God. He bestows it on His timetable and purpose, not ours." Another clinical psychologist said that there is nothing a scientist can do and that "Gifts like inspiration come from God, independent of human activity.

\section{Further Thoughts on Inspiration}

The questionnaire also asked respondents to share other thoughts they had regarding inspiration in science. Participants responded to the question, Do you have any other thoughts about the role of inspiration in science that you would like to share? by 
(a) defining inspiration, (b) describing the source of inspiration, (c) sharing their testimony of inspiration or God, (d) encouraging the inclusion of inspiration in science, (f) offering recommendations for the investigators. Participants also responded to this question in ways that corresponded to themes reported under the previous two questions: (1) Could you please describe an occasion when you have experienced inspiration in your scholarship or scientific endeavors? or What, if anything, do you believe scientists and scholars can do to qualify for and receive inspiration? As these responses have already been included in the analysis and shared in the description of responses to those questions, they will not be repeated here. The following are descriptions and examples of themes that have not been previously reported. Themes are discussed in a narrative fashion with representative quotes and outlined in Table 4 below.

Table 4

Other Thoughts Participants had About the Role of Inspiration in Science

Other thoughts scientists had about inspiration

(a) defining inspiration

(b) describing the source of inspiration

(c) sharing their testimony of inspiration or God

(d) encouraging the inclusion of inspiration in science

(e) offering recommendations for the investigators 


\section{Definitions for inspiration}

Some respondents used the open-ended nature of the question, Do you have any other thoughts about the role of inspiration in science that you would like to share? to share their definitions of inspiration. They shared their understanding of the ways inspiration does and does not manifest in scientific pursuits. For instance, a clinical psychologist shared the following:

I'm influenced by the archaic meaning of 'inspire,' which is 'to breathe into.' I think that God is constantly breathing into us. Inspiration is commonly thought of as involving some idea that results from cognition makes it too narrow, though. A professor of sociology stated “There may be (although frankly I don't know) a difference between inspiration and "God's inspiration." And these may have little or much to do with faith." A pastoral psychologist wrote the following:

All inspiration is of God. This experience can be described in theological and psychological terms. These languages are different and use different tools. However since they are describing the same experience of a human being, the descriptions should be in harmony.

A respondent with a masters' degree in theology and education reported the following: Inspiration like creativity takes discipline. Inspiration is not serendipity, but a disciplined attempt to use all resources to make a creative approach to the problem. The entire notion of New Paradigm comes from the notion that current ways of knowing do not explain a new situation. To recognize the failure of conventional knowledge is a disciplined way to open oneself for new inspired possibilities. 


\section{Sources of Inspiration}

Other participants responded by describing possible sources of inspiration. They described inspiration as coming from a divine source that existed beyond the limitations of self. For instance, a professor of educational psychology asserted, "I think it happens all the time, but many folks don't want to admit that the source of their 'great idea' might not be THEM!" A professor of microbiology said the following:

I don't think many would argue that 'inspiration' can be and has often been an enabling force in the lives of men and women in all walks of life. The question is, 'From whence comes such inspiration?' Are we simply hard wired for inspiration and it occurs sometimes as a natural physiological response to psychophysiological events, or does God intervene in the lives of men and women in whom He finds favor? I know not what conclusion others may draw, but for me, God's beneficial involvement in my life is undeniable. I see his hand and feel His presence in all I do.

An aerospace engineer stated the following:

This is true in all areas and activities, but especially for scientific and technical efforts; if we take unselfish approach and truly desire to glorify our Creator and to benefit the mankind then God will bless our efforts. All knowledge comes from God and God will guide our growth in knowledge and our use of it. The ungodly approaches lead to the abuses of knowledge.

A professor of chemistry wrote the following:

I believe that all scientific discovery (or perhaps I should say all discoveries pertaining to physical reality, laws of nature, and similar truths of an eternal 
character) is/are inspired by God. Many discoveries of this type have been made by decidedly irreligious men. However, one must ask, what was the source of the fundamental truth that was discovered? The mind of an atheist may well be the first human mind to conceive of a heretofore never-considered idea. However, if the 'idea' is an eternal truth, the 'idea' exists independently and is only made known to the rest of humanity through the instrumentality of the so-called 'discoverer.' The independent existence of the "discovered" truth implies that it was not created by the 'discoverer' and that the discoverer, however irreligious, was allowed to conceive of its essence. In that sense, all scientific discoveries are revelations.

\section{Testimony of Inspiration or God}

Some respondents used this space on the questionnaire to share their testimonies of inspiration or God. They shared their views about the importance of inviting and acknowledging God in scientific pursuits. For instance, a counseling psychologist reported, "I believe that God is always trying to bring about good - to make all things work for our good and that there are few other professions that have the tremendous opportunities that we have...." A professor of food science stated, "I don't believe that [religious] scientists have a corner on divine help. But we are sensitized to the process and should be able to more readily tap into it." A chemist asserted, "I believe man's greatest achievements are inspired and assisted by God." A psychiatrist with a PhD in philosophy stated the following:

I am a psychiatrist. It has been remarkable to me during the course of my practice how many times MY PATIENTS' faith, their commitment to pray for me, their 
obvious trust in God, their deep experiences of God, etc. INSPIRE ME, DEEPEN MY FAITH, COMPELL ME TO TRUST GOD MORE. Although they come to me for help with their lives, it is amazing how they often inspire me and thereby enrich my life."

A respondent with a master's degree in ministry said the following: I most certainly do. There are many scientists who ARE receiving Divine guidance and are using it in their current research work. They are developing amazing solutions to the world's most critical problems. But, because of our current society's view on Divine Inspiration they do not have a very welcome place to announce their discoveries. This is not only keeping the discoveries away from those who need it, it is keeping technology and science as a whole in the slow lane of advancement. But happily, there and more and more people becoming enlightened by God's inspiration and their intuitive abilities every day. Those with the will to stand up and fight for what is true and right, just like our forefathers did, will be able to bring their ideas and discoveries to the world. They will be laughed at for giving credit to the Divine, but they will understand that they and the Divine can take it, for it is not the personal emotions that count, it is the effect of their discovery on the population of the world. And they will feel privileged to have been asked by the Divine to bring this to the world, they will not feel proud and self-righteous, they will feel honored for the opportunity to work with God as His assistant in bringing the item to the world.

A psychology professor said the following: 
All of life is a grand aid in inexplicable mystery. If one is open to receiving giftsinspiration, confirmation, affirmation- from God then surely God influences these human endeavors. Scholarship, science, therapy are all human activities that suffer from all of the ambiguities of existence but can be enhanced if we are open to God's intervention. The hard work is to become, and remain, open to these mysteries-or better-the mysterious ways that God works in the world.

\section{Inclusion of Inspiration in Science}

Other participants answered the questions by sharing their endorsement for including inspiration in science. These responses included encouragement of the inclusion of inspiration and God in science, as well as urging scientists to have courage to look beyond the naturalistic perspective of science. For instance, a professor clinical psychology stated, "I think that inspiration has played in important role throughout the history of science and many world-renowned scientists have acknowledged this." A respondent with an MD reported the following: I believe God is present in all things, animate and inanimate. We can receive wisdom, guidance, inspiration, truth at any time in any place. We need to be receptive, awake, open to the possibilities that love has for our world or our life. We also need to be part of a community that will help us grow in receptivity. We need people who will help us explore, who will not be judgmental, who are not threatened by new ideas or experiences. We need friends who have some spiritual maturity or a mentor or spiritual director with whom we can share our experiences. The more we are able to talk about night dreams, visions, crazy 
ideas, numinous experiences, etc. the more we affirm their validity and the more we will have them.

A professor of psychology stated the following:

I've often felt frustrated that I'm not more free to share my experience of faith with clients - if they ask, of course I do - but I feel psychotherapy can remove barriers and free a person to make choices he/she could not otherwise have made - but one still needs a philosophy or a religious faith to paint a direction. Happily, there's a little more recognition of that today in the field of psychology.

A civil engineer said the following:

I would like to see studies that correlate theological principles with psychological principles. I see many similarities in these that are often ignored. Just as myths reflect theology, psychology also mimics theology in a more scientific way. For example, prayer vs. meditation, confession vs. counseling, salvation vs. identity, revelation vs. subconscious decisions, faith vs. confidence, etc.

A professor of community development wrote the following;

Being willing to keep going on inquiry when the gatekeepers of one's profession are not prizing your efforts (at least at the beginning). Being willing to risk going a direction that may not be rewarded by the profession or tenure and promotion, being willing to pursue lines of inquiry that are not considered valid for 'secular' professionals to engage in, being willing to act on a feeling that you should go in a certain direction even when it might not be able to be proven through traditional avenues of literature reviews, [previous] research, etc. 


\section{Recommendations for the Investigators}

Other participants also responded to the question by offering recommendations. They shared suggestions for future work in this area of study. For instance, a professor of theology said, "Many people feel inspired to do their professional work without any reference to religion. But many others count on their religion to give them both (intellectual) reasons and inspiration to continue in their work. If you do, just ask a religious professional whom you trust to enlighten you about what the religious tradition has had and currently has to say about the kind of work you do. It can't hurt!” A respondent with a $\mathrm{PhD}$. in counseling psychology suggested, "I subscribe to several newsletters and magazines which support, fund and promote research about the interface between science and religion/spirituality. This research and those involved need to be brought more into the mainstream. The helping professions need to take spiritual needs seriously by requiring at least one course in this area for graduation and/or certification." A professor of mathematics said, "I'm happy to see that someone is studying the process. I have thought that it would be nice to teach a group of scientists how to meditate effectively and see if their level of inspiration increased." A clinical psychologist recommended, "None. Just interested that you are exploring the area. A more structured survey may be a next step."

\section{Naturalistic/Atheistic Views of Inspiration}

A few of the respondents did not believe God inspired scientists in their work. They described that stage of the process more atheistically, such as a professor of biology who said, "After one has tried something over and over again, and based on work of 
others, one often gets an idea to try something else. To call it inspiration is in the eyes of the beholder." A doctor of ministry said the following:

As a Presbyterian minister coming from a liberal perspective, I think I would have to say no, and simply believe that the human spirit is the only guiding source of inspiration in my life's efforts to be of some use to humanity. 


\section{Discussion \\ Reflection on Research Themes}

Research has shown that many modern day behavioral and natural scientists throughout the nation do believe in God and are interested in spirituality (Ecklund, 2006; Gross \& Simmons, 2006). Many scientists participate in religious or spiritual practices to enhance their spiritual sensitivity. This study was designed to increase our understanding about how scientists who believe that God can inspire them experience His influence in their scholarly and discovery pursuits. This study was also intended to provide insight into whether or not these scientists believed scientists could prepare to receive inspiration in their work and what that preparation might include. Findings from this study support a theistic view of science that asserts that spiritual influences can aid us in better understanding phenomena (Jones, 1994, Richards \& Bergin, 2005).

Data analyses yielded several themes of responses within the areas of (a) experiences with inspiration, (b) how to prepare to receive inspiration, and (c) further thoughts on inspiration in science. The theistic scientists from this study came from a variety of religious backgrounds and scientific fields, yet they shared many commonalities in their experiences with and preparations for receiving inspiration in their work. The scientists in this study reported that they experience inspiration throughout various stages of the research and discovery process. Many of them also reported that openness to God's guidance in their work and a recognition of His influence seems to contribute to their ability to make discoveries and important scholarly contributions. A small number of respondents did not believe God inspired scientists in their work. However, the vast majority of respondents believed God can inspire scientists and many 
of them shared their experiences with God's influence in their scientific and scholarly endeavors.

Neal E. Miller described the research process as including a discovery and proof stage (Bergin \& Strupp, 1972). It is during the discovery phase that he suggests that creative and intuitive process can be helpful. Similarly, Wallas (1926) suggested that discoveries and new ideas originate through a process of four stages: the preparation stage, the incubation stage, the illumination stage, and the verification stage. Scientists in this study described experiencing inspiration throughout all four of these stages.

\section{Experiences with Inspiration}

Participants reported experiencing inspiration or divine guidance at every stage of the scientific process. They described experiencing inspiration during the preparatory stage as they chose their area of study and a specific research topic to pursue. They described feeling divine assistance in obtaining the resources needed to pursue the research and carry out the project, including feeling God's help in overcoming obstacles that threatened to hinder their projects. Scientists also reported experiencing inspiration in choosing who to work with on their projects including collaborators and research assistants.

Some scientists also reported feeling inspired by God during the incubation stage. They reported that they received inspired insights as they set their projects aside for a time either because they felt stuck and decided to pursue another more relaxing activity, or because they had purposefully incorporated an incubation period into their approach to science. 
Respondents also reported feeling inspiration during the illumination or discovery stage. During this stage, participants reported receiving insights and spiritual manifestations from God during data synthesis and integration and in comprehending important connections or patterns within the data, and discovering solutions to theoretical and technical problems. Other scientists reported that God enhanced their level of creativity and expressive ability while interpreting their data and writing up their findings.

Some scientists even reported feeling divine inspiration during the verification stage of discovery, such as finding the evidence for an idea or discovery that they had made. Additionally, participants reported feeling inspiration during training and teaching experiences and through their study of and engagement in nature.

The way a number of respondents described their experiences with inspiration was consistent with the way some well known scientists have reported their experiences with inspiration. For example, some of the participants described this experience as a spiritual manifestation or seeing a picture in their "mind's eye," similar to the German chemist, Kekule von Stadonitz who described "seeing" the cyclic structure of benzene (Bergin, 1979). Others experienced inspiration as a flash of insight similar to physicist, Paul Davies' description of a “ shortcut to truth”( 1992, p. 228), or physicist Fred Hoyle’s description of a " huge brilliant light... suddenly been switched on" (1981, p. 43). This moment of insight described by participants in this study is similar to psychologist, Csikszentmihalyi's description of the "Aha!" moment when the "pieces of the puzzle fall together" (1992, p. 80). He suggested that there may be several times of insight "interspersed with periods of incubation, evaluation, and elaboration" (p.80). Some 
scientists in this study described feeling inspired to go beyond their natural abilities, similar to Roger Penrose's description of mathematical inspiration as a sudden breakthrough into another realm (Davies, 1992). In addition, respondents described experiencing inspiration in the form of serendipity. ${ }^{1}$ Others reported experiencing inspiration as a physical or emotional sensation affirming God's presence or influence in their work. A few respondents said that they recognized God's inspiration as a sense of being called or divinely motivated to pursue their particular area of study. These respondents felt that God had led them to a particular career or research focus and made it possible for them to honor that calling. Some respondents also described feeling guided by God or feeling his inspiration as a constant presence throughout the scholarly and scientific process. They did not distinguish specific instances but rather affirmed that God was ever present and interested in their work.

\section{Preparing to Receive Inspiration}

The second purpose of this study was to learn if the scientists in this study believed that there were things that scientists could do to help them prepare to receive inspiration in their work. Researchers interested in the study of creative scientists have learned that creative scientists share many of the same characteristics and participate in particular habits that seem to prepare them for the discovery process (Richard \& Busse, 1981; Simonton, 2004). Likewise many scientists in our study felt that there are things that scientists can do that may help them to qualify to receive and recognize inspiration in

\footnotetext{
${ }^{1}$ Serendipity has been defined as "the gift for finding valuable or agreeable things not sought for or the faculty of making fortunate and unexpected discoveries by accident” (Roberts, 1989, p. ix).
} 
their scientific endeavors (Mansfield \& Busse, 1981; Richards \& Bergin, 2005; Simonton, 2004). There were also some respondents who stated that there is nothing scientists can do to qualify to receive inspiration because inspiration is a free gift from God that is "independent of human activity."

From those participants who did believe that there are things scientists can do to prepare to receive inspiration, the most prominent suggestion that respondents had for scientists was that they remain open to alternative ways of gaining insights, particularly insights from God. This suggestion corresponds with research that has found that creative scientists tend to be open to breaking traditional constraints of science (Mansfield \& Busse, 1981; Simonton, 2004). Similar to suggestions offered at the conference hosted by the Templeton foundation and the American Scientific Society that scientist pray for divine guidance in choosing a research topic and in other areas of the research process, scientists in our study encouraged scientists to pray to prepare to receive God's inspiration in their work (Templeton, 2000).

Another recommendation that participants offered to scientists was that they should try to be humble and submit to God's will in regards to their research endeavors. Along with this suggestion, theistic scientists in our study suggested that scientists should express gratitude and a sense of wonder and awe about God's creation and His assistance in their work. Participants in this study recommended that scientists develop and nurture a relationship with God. They felt that by being in a relationship with God, scientists may more readily receive and accept God's influence in their work. Respondents also reported that they felt scientists who live morally sound or virtuous lives and who have altruistic motives behind their scientific and scholarly pursuits may be more likely to receive 
inspiration in their scientific endeavors. Other participants suggested that scientists who read religious texts such as the Holy Bible may be more open to and aware of God's inspiration in their work. Consistent with the findings of a study conducted by the Higher Education Research Institute, which found that many academic scientists practice meditation, some respondents in this study suggested that spiritual meditation can help scientists prepare to receive inspiration in the research and discovery process (Astin \& Lindholm, Ct). Along with meditation, some participants discouraged scientists from becoming overly dependent on the need to "touch it or measure it-- prove" it, but to be willing to listen to spiritual promptings or insights. A few participants suggested that inspiration was more likely to take place within the dialogue. They felt that God may provide inspiration through their conversations with others.

Finally, several theistic scientists in this study suggested that scientists who are willing to be disciplined and work hard on "the problem at hand" may be more qualified to receive inspiration throughout the scientific process than other scientists. As one participant suggested, "put in the work and exhaust all possible tests and observation - let go of it for a season, providing time for incubation and the subconscious to activate focus when new ideas and connections begin to flow." The importance of discipline and hard work, as well as providing time for incubation, is consistent with the findings of Wallace (1926) and Csikszentmihalyi (1996) who conducted research about scientists and creativity.

\section{Further Thoughts on Inspiration}

Spirituality and religion was excluded from the scientific process and from scientific inquiry during the Enlightenment and Renaissance era when an overdependence 
on naturalistic assumptions was acquired (Burtt, 2003; Fergren, 2002; Leon, 1999; St. Claire 1985; Keener, 1983). Scientists and scholars who wished to consider spiritual phenomena or to include God in the process were usually marginalized (DiClemente \& Delaney, 2005a; Johnson, 1993; Slife \& Nebeker, 1999). Although these restrictions are being reconsidered in science today, many scientists still feel limited by the constraints of naturalistic expectations in scholarship and discovery. When given the space to share more of their thoughts about inspiration in scholarship and discovery, some participants expressed their frustration with these constraints and their enthusiasm and encouragement for a new, more spiritually friendly zeitgeist. Other participants used this space on the survey to describe what they perceived to be the source of inspiration. These responses referred to the source of inspiration as God or the Holy Spirit. Respondents also included suggestions they had for future research in this area of study. Some participants shared their definitions of inspiration while others expressed their testimony about God or his inspiration in the research and discovery process. They suggested that as scientists are open to receiving God's inspiration in their work, that $\mathrm{He}$ will enhance their abilities and guide their processes. As one respondent suggested, "Scholarship, science, [and] therapy are all human activities that suffer from all of the ambiguities of existence but can be enhanced if we are open to God's intervention. The hard work is to become, and remain, open to these mysteries-or better-the mysterious ways that God works in the world."

\section{Observations of the Researcher}

This research study was conducted to learn more about the ways theistic scientists experiences inspiration in their scholarly and research activities, and to learn about suggestions that they may have for other scientists to help them prepare to receive God's 
inspiration in their work. This study was conducted from a theistic perspective, which means that the principal investigator and dissertation chair began the analyses with the assumption that God does indeed exist and that He can and does inspire some scientists in their work. Theistic assumptions were an essential aspect of the data analyses conducted. These assumptions influenced every stage of the research process in this study. As the researchers formulated their research questions, prepared the survey, and analyzed and interpreted the data, they sought to be open throughout the study to the possibility that God may inspire scientists and scholars as well as to the possibility that not all respondents would agree with this view. It is the researcher's belief that their assumptions did not undermine the trustworthiness of the findings or their portrayal of the respondents' views. Multiple coders were used in analyzing the data, an outside auditor was employed, and direct quotes from the participants were obtained to support each theme in order to help ensure the trustworthiness of the study.

The overall impressions of the researcher are that this study supports a theistic view of science which asserts that inspiration may enhance the scientific process and aid scientists in their scholarly and scientific endeavors (Delaney \& DiClemente, 2005a; Richards \& Bergin, 2005). Results from this study suggest that many theistic scientists are having experiences with inspiration throughout all stages of the research process. They do not seem to be saying that the modern conception of the scientific process has to be abandoned, but rather that a theistic conception of it helps scholars to be more productive in their research. They seem to be suggesting that inspiration is a valid and useful way of gaining insight and guidance throughout the scholarly and discovery process. 
It is of interest to note that scientists from this study come from both the behavioral and the natural sciences as well as from a diversity of religious backgrounds, yet they seem to share much in common in the ways they discuss the need for inspiration in science and their personal experiences with it. There are very few, if any, studies that bring both sides of science together in the study of spiritual phenomena in science. A number of natural science researchers have studied the interface of science and religion, spirituality, or theism; and many social scientists have investigated the role of spirituality, religion, or theism in psychology or psychotherapy. However, this study is unique in that it pulls the two worlds together under the bigger umbrella of scientists interested in spirituality or theism. The findings of the present study provide some evidence that some scientists and scholars across all fields of science and across a variety of religious traditions believe that God inspires them in their work. Most of the participants in this study believe that inspiration is a very real phenomenon that enhances their experience and performance as scientists. The scientists in our study concur with some other scientists in the view that some of the great discoveries and scientific advancements of our day have come about through divine assistance.

It is also of interest to note that many of the theistic scientists in our study believe that there are things that scientists can do to qualify for or be open to inspiration, they encouraged the scientific community to be willing to look beyond the traditional constraints of naturalistic science and allow for divine influences to guide the process. In addition, they expressed their view that it is not only important to earn the degree, gather the data, and do the work, but that it is also important to live a life that welcomes God's 
influence in scientific pursuits. For many theistic scientists, having God involved in the process makes the process more meaningful and effective.

\section{Limitations of the Study}

There were some limitations to the study. The findings in this study are not generalizable beyond the sample of participants. Consistent with the qualitative research tradition, it was not the goal of this study to generalize our findings beyond the participants of the study. This study was designed to learn how scientists who believe in God experience inspiration in their scientific scholarship and discovery. It was not designed to learn the percentage of scientists who believe in inspiration or who experience inspiration. Due to the focus of this study, the researchers targeted populations that tended to be theistic and that would be more likely to want to share their experiences with inspiration. Although there were a small number of respondents who were atheistic or agnostic, the aim of the study was to learn about inspiration in science from those who identified themselves as theistic.

The second limitation was that the principle investigator and the dissertation chair had in common certain beliefs about the role of inspiration in science. They believe that God does inspire scientists and that a theistic perspective of science can enhance the scientific process. As previously acknowledged, these beliefs influenced every stage of the research conducted. All researchers have values and perspectives and all studies are conducted upon assumptions that support those values and perspectives. The topic of study, the questions asked, the population selected, the interpretation of data and the writing up of findings are all influenced by researchers' perceptions and values. Theistic perspectives are likely no more or less influential on the process than naturalistic 
perspectives. Perhaps due to a history of criticism against theistic investigations, it is possible that theistic researchers are more sensitive to and aware of their perspectives and values than those working from a naturalistic perspective. Further both investigators are members of the Church of Jesus Christ of Latter-day Saints. This may have influenced the way responses were interpreted; however direct quotes were used from the participants to help represent responses accurately. In addition, perspectives and values in this study have been made explicit and checks were put into place, including employing a non-LDS, outside auditor of the study, to help broaden the scope of what might be learned from this study.

The survey nature of the study also created limitations to the study. Personal interviews would have provided more in-depth responses and may have fit better with some aspects of a grounded theory approach. However, given that this study was exploratory in nature (no study to date has gathered information of this nature) the investigators chose to gather a breadth of information as opposed to depth.

\section{Recommendations for Future Research}

This study helped verify that inspiration in science could be a fruitful area of investigation. Future studies might include lengthy personal interviews to gain a greater depth of knowledge about scientists' experiences with inspiration. Investigators may want to select a handful of theistic scientists who assert having experienced inspiration in their work and ask them to share in greater depth their experience. This study was conducted qualitatively. It could be interesting to learn through quantitative methods the prevalence of scientists who believe in inspiration or experience inspiration in their work. Future investigations might randomly sample scientific communities and collect data that would 
answer those questions and be more generalizable to the larger scientific community. Future studies might also explore specific demographic variables carefully to consider difference between those variables and scientists experiences with God in their work. This could help us better understand how various demographic indicators influence people's experiences with inspiration. Another possible area of investigation for future studies is to explore various epistemologies and their influence on scholarly and scientific endeavors. Researchers could consider the contributions and/or differences between authority, empiricism, reason, and inspiration in the scientific community. Future research by behavioral scientists could examine the role of inspiration within their specific area of study. For instance they may want to investigate the prevalence and role of intuition, inspiration, and divine intervention in therapeutic change and healing.

\section{Conclusion}

The climate is warming towards theistic views of science. Scientists throughout the nation are identifying themselves as believers in God and as having interest in spirituality (Austin \& Lindholm, Ct; Bartless, 2006; Gross \& Simmons, 2006). Serious scholars from both the behavioral and natural sciences are beginning to consider theistic spirituality as both an important area of investigation as well as a valuable perspective for investigating (Jones, 1994; Richards \& O'Grady, 2003). Objective, empirical ways of gaining knowledge along with rational ways of knowing have contributed much to the scientific process (Burt, 2003; Leon, 1999).

This study supports the view that inspiration may also enrich the scientific process. It may provide added avenues for insight and enhance both natural and behavioral scientists in their specific areas of investigation. Respondents to this study 
suggest that God's inspiration has played an important role for them in the scientific process and contributed greatly to their scientific advancements. Findings from this study support a theistic view of science which assumes that scientists can receive divine assistance in their efforts. It is hoped that this study will help encourage theistic scientists to seek inspiration and to be open to God's influence in their scholarship and discovery endeavors. 


\section{References}

Arthur, A.R. (2001). Personality, epistemology and psychotherapists' choice of theoretical model: a review and analysis. Eur. J. of Psychotherapy, Counseling \& Health, 4, 45-64.

Astin, A.W., \& Astin, H.S. (Ct). Higher Education Research Institute. Spirituality in Higher Education: Overview of a National Study. Retrieved November 4, 2006, from http://www.spirituality.ucla.edu.

Bartlett, T. (2006, October). Most scientists at elite universities consider themselves 'spiritual,' survey finds. Today's News. Retrieved November 4, 2006, from http://chronicle.com/daily/2006/10/2006103105n.htm.

Berg, B.L. (2004). Qualitative research methods for the social sciences $\left(5^{\text {th }}\right.$ ed.). Boston: Pearson.

Bergin, A. E. (1979). Bringing the restoration to the academic world: Clinical psychology as a test case. Brigham Young University Studies, 19, 449-473.

Bergin, A. E., \& Strupp, H. H. (1972). Changing frontiers in the science of psychotherapy. Chicago: Aldine-Atherton.

Blackwell, R.J. (2002). Galileo. In G.B. Ferngren (Ed.), Science and religion: a historical introduction (pp.105-116). Baltimore: The John Hopkins University Press.

Brooke, J.H. (1996). Science and theology in the enlightenment. In W.M. Richardson \& W.J. Wildman (Eds.), Religion and science: History, method, dialogue (pp. 7-28). New York: Routledge.

Burrt, E.A. (2003). The metaphysical foundations of modern science. Minola, NY: Dover. 
Brigham Young University, General Information (Ct). retrieved August 10, 2006, from http://unicomm.byu.edu/about/factfile.

Clayton, P. (2003, October). A program ends, the quest for science-and-religion continues. Research News \& Opportunities in Science and Theology, 4 (2), 2-3, 33.

Clark, R.W. (1971). Einstein: The life and times. New York: World.

Crouch, C. H. (2002). Is scientism the predominant religion of scientists? Perspectives on Science and Christian Faith, 54 (1), 30-32.

Csikszentmihalyi, M. (1996). Creativity: Flow and the psychology of discovery and invention. New York: Harper Perennial.

Davies, P. (1992). The mind of God: The scientific basis for a rational world. New York: Simon \& Schuster.

Davis, E.B., \& R. Collins (2002). Scientific naturalism. In G.B Fergnren, (Ed),. Science and religion: A historical introduction (pp.323-334). Boston: John Hopkins Press.

Delaney, H.B., \& DiClemente, C.C. (2005a). Implications of Judeo-Christian views of human nature, motivation, and change for the science and practice of psychology. In W.R. Miller \& H.D. Delaney (Eds.), Judeo-Christian perspectives on psychology. Washington, DC: American Psychological Association.

Delaney, H.B., \& DiClemente, C.C. (2005b). Psychology’s roots: A brief history of the influence of Judeo-Christian perspectives. In W.R. Miller \& H.D. Delaney (Eds.), Judeo-Christian perspectives on psychology. Washington, DC: American Psychological Association. 
Dembski, W.A, \& Kushiner, J.M. (Eds). (2001). Signs of intelligence: Understanding intelligent design. Grand Rapids, Michigan: Brazos Press.

Dembski, W.A. (1999). Intelligent design: The bridge between science \& theology. Downers Grove, IL: InterVarsity Press.

Dixon, T. (2002). Scientific atheism as a faith tradition. Stud. Hist. Phil. Biol. \& Biomed. Sci., 33, 337-359.

Ecklund, E.H. (2006). Initial findings from the study of religion among academic scientists (RAAS). A working paper, prepared October 2006.

Erlandson, D.A., Harris, E.L., Skipper, B.L., \& Allen, S.D. (1993). Doing naturalistic inquiry: A guide to methods. Newbury Park, CA: Sage.

Fear, R., \& Woolfe, R. (1999). The personal and professional development of the counselor: the relationship between personal philosophy and theoretical orientation. Counseling Psychology Quarterly, 12, 253-262.

Ferngren, G.B. (2002). Science and religion: A historical introduction. Boston: John Hopkins Press.

Godel, K. (1990). What is Cantor's continuum problem? Supplement to the Second Edition, In S. Ferferman et al. (Eds.), Collected works, Vol. II (pp. 266-269). New York: Oxford University Press.

Griffin, D.R. (2001). Reenchantment without supernaturalism: A process philosophy of religion. London: Cornell University Press.

Gross, N., \& Simmons, S. (2006). How religious are America's college and university professors? Working paper, prepared October, 2006. 
Guiffrida, D.A. (2005). The emergence model: An alternative pedagogy for facilitating self-reflection and theoretical fit in counseling students. CounselorEducation \& Supervision, 44,201-213.

Henwood, K., \& Pidgeon, N. (2003). Grounded theory in psychological research. In P.M. Camic, J.E. Rhodes, and L.Yardley (Eds.). Qualitative Research in Psychology: Expanding perspectives in methodology and design. Washington, DC: American Psychological Association.

Honer, S. M., \& Hunt, T. C. (1987). Invitation to philosophy: Issues and options (5th ed.). Belmont, CA: Wadsworth.

Hoyle, F. (1981). The universe: Past and present reflections. University of Cardiff report.

Johnson, B., \& Christensen, L. (2004). Educational research: quantitative, qualitative, and mixed approaches: $\left(2^{\text {nd }}\right.$ ed.). Boston, MA: Pearson.

Johnson, P.E. (1993). Reason in balance: The case against naturalism in science, law, and education. Downers Grove, IL: InterVarsity Press.

Jones, R.H. (1986). Science and mysticism: A comparative study of western natural science, Theravada Buddhism, and Advaita Vedanta. London: Bucknell University Press.

Jones, S. L. (1994). A constructive relationship for religion with the science and profession of psychology: Perhaps the boldest model yet. American Psychologist, 49, 184-199.

Kazdin, A.E. (2003). Research design in clinical psychology (4th ed.). Boston, MA: Allyn and Bacon. 
Keener, F. M. (1983). The chain of becoming: The philosophical tale, the novel, and a neglected realism of the Enlightenment: Swift, Montesquieu, Voltaire, Johnson, and Austen. New York: Columbia University Press.

Kemp, K.W. (1998). The virtue of faith in theology, natural science, and philosophy. Faith and philosophy, 15, 463-477.

Leahey, T. H. (1991). A history of modern psychology. Englewood Cliffs, NJ: Prentice Hall.

Leon, J.C. (1999). Science and philosophy in the west. Upper Saddle River, NJ: Prentice Hall.

Lindberg, D.C. (2003b). Galileo, the church, and the cosmos. In D.C. Lindberg \& R.L. Numbers (Eds.), When science and Christianity meet. Chicago: The University of Chicago Press.

Lindberg, D.C (2003a). The medieval church encounters the classical tradition: Saint Augustine, Roger Bacon, and the handmaiden metaphor. In D.C. Lindberg \& R.L. Numbers (Eds.), When science and Christianity meet. Chicago: The University of Chicago Press.

Mansfield, R.S., \& Busse, T.V. (1981). The Psychology of creativity and discovery: Scientists and their work. Chicago: Nelson-Hall.

Merton ,R.K., \& Barber, E. (2004). The travels and adventures of serendipity. Princeton, NJ: Princeton University Press.

Miller, K.R. (1999). Finding Darwin's God: A scientist's search for common ground between God and evolution. New York: Harper. 
Miller, W.R.. (2005). What is human nature? Reflections from Judeo-Christian perspectives. In W.R. Miller \& H.D. Delaney (Eds.), Judeo-Christian perspectives on psychology. Washington, DC: American Psychological Association.

Mooney, C.F. (1996). Theology and scientific knowledge: Changing models of God's presence in the world. Notre Dame, IN: University of Dame Press.

Numbers, R.L. (2003). Science without God: Natural laws and Christian beliefs. In D.C. Lindberg \& R.L. Numbers (Eds.), When science and Christianity meet. Chicago: The University of Chicago Press.

Padgett, A.G. (2002). Dialetical realism in theology and science. Perspectives on Science and Christian Faith, 54, 184-192.

Palmer, S.J., R.R. Keller, D.S. Choi, \& J.A. Toronto (1999). Religions of the world: A Latter-day Saint View. Provo, UT: Brigham Young University.

Peacocke, A. (2001). Paths of science towards god: The end of all of our exploring. Oxford, England: Oneworld.

Percesepe, G. (1991). Philosophy: An introduction to the labor of reason. New York: Macmillian.

Pidgeon, N. (1996). Grounded theory: Theoretical background. In T.E. Richardson (Ed.) Handbook of qualitative research methods for psychology and the social sciences: Leicester, UK: The British Psychological Society.

Pidgeon, N., \& Henwood, K. (1996). Grounded theory: Practical implementation. In T.E. Richardson (Ed.) Handbook of qualitative research methods for psychology and the social sciences: Leicester, UK: The British Psychological Society. 
Plantinga, A. (1993). Warrent and proper function. New York: Oxford University Press.

Polkinghorne, J. (1998). Belief in God in an age of science. New Haven CT: Yale University Press.

Richards, P.S., \& O'Grady, K.A. (2003). Out of obscurity: The faith factor in physical and mental health. Contemporary Psychology, 48, 612-614.

Richards, P.S., \& Bergin, A.E. (1997). A spiritual strategy for counseling and psychotherapy. Washington DC: American Psychological Association.

Richards, P.S., \& Bergin, A.E. (2005). A spiritual strategy for counseling and psychotherapy ( $2^{\text {nd }}$ ed.). Washington DC: American Psychological Association.

Roberts, R.M. (1989). Serendipity: Accidental discoveries in science. New York: Wiley $\&$ Sons.

Shapiro, G. (1986). A skeleton in the darkroom: Stories of serendipity in science. San Francisco: Harper \& Row.

Shafranske, E.P. (Ed). (1996). Religion and the clinical practice of psychology. Washington, DC: American Psychological Association.

Simonton, K.D. (2004). Creativity in science: Chance, logic, genius, and zeitgeist. Cambridge UK: Cambridge University Press.

Slife, B. D. (2004). Theoretical challenges to therapy practice and research: The constraint of naturalism. In M. J. Lambert (Ed.), Bergin and Garfield's handbook of psychotherapy and behavior change ( $5^{\text {th }}$ ed., pp. 44-83). New York: Wiley.

Slife, B.D., \& Gantt, E.E. (1999). Methodological pluralism: A framework for psychotherapy research. Journal of Clinical Psychology, 55, 1453-1465. 
Slife, B.D., Hope, C., \& Nebeker, R.S. (1999). Examining the relationship between religious spirituality and psychological science. Journal of Humanistic Psychology, 39, 51-85.

Sperry, L., \& Shafranske, E.P. (Eds.). (2005). Spiritually oriented psychotherapy. Washington DC: American Psychological Association.

Strauss, A., \& Corbin, J. (1990). Basics of qualitative research: Grounded theory procedures and techniques. Thousand Oaks, CA: Sage.

St. Claire, E. B. (1985). The why of science and the how of religion. Tradition \& Discovery: The Polanyi Society Periodical, 20, 5-15.

Sue, S. (1999). Science, ethnicity, and bias: Where have we gone wrong? American Psychologist, 54, 1070-1077.

Suppe, J. (2001). How does God guide our decisions? Perspectives on Science and Christian Faith, 53, 221-224.

Templeton, J. (2000). Possibilities for over one hundredfold more spiritual information: The humble approach in theology and science. Randor, PA: Templeton Foundation Press.

The American Heritage ${ }^{\circledR}$ Dictionary of the English Language, Fourth Edition, 2000, Houghton Mifflin Company

Wallas, G. (1926). The art of thought. New York: Harcourt Brace.

Watson, F. M. (2006). Statistical report, 2005. Ensign, May, 24.

Whitehead, A.N. (1967). Science and the modern world. New York: Free Press. (Original work published 1925). 
Worthington, E.L.(1998). Dimensions of forgiveness: Psychological research and theological perspectives. Philadelphia: Templeton Foundation Press.

Worthington, E.L., Jr., \& Sandage, S.J. (2001). Religion and spirituality. Psychotherapy, $38,473-478$. 


\section{Appendix A}

Dear Dr. (last name):

I would like to invite you to participate in a research study about the role of inspiration in science and the practice of psychotherapy. You have been selected to participate in our study because of your professional expertise as a scientist and/or psychotherapist. Inspiration has been defined as "divine guidance or influence exerted directly on the mind and soul of humankind" (The American Heritage ${ }^{\circledR}$ Dictionary of the English Language, Fourth Edition, 2000, Houghton Mifflin Company). Historically some scientists and scholars have acknowledged intuitive or inspirational influences as contributing factors to the scientific and creative processes (e.g. Albert Einstein, Neil Miller, Kekule von Stadonitz). Some mental health professionals have also discussed the role of intuition or inspiration in psychotherapy practice (e.g., Allen Bergin, Carl Rogers, William West). Despite this, little is empirically known regarding the role of inspirational experiences in science or psychotherapy. We think it is important to more adequately explore and document this phenomenon in the lives of contemporary behavioral scientists and psychotherapists. We hope you will help us in this effort by sharing your views and experiences about inspiration by responding to the enclosed brief questionnaire. We believe that the findings from this study will help scholars and students better understand the role of inspirational experiences in behavioral science research and practice. Please respond to the enclosed questionnaire at you earliest convenience. If you would prefer to complete the survey online, you can do so by going to the following link: http://www.surveymonkey.com/s.asp? $\mathrm{u}=14887406031$ If you choose to complete the survey online, please enter your ID\# on the online survey so that we know you have completed it and don't contact you again (see $4^{\text {th }}$ page of enclosed survey for your ID\#). Thank you for your assistance. Please feel free to contact me if you have any questions about this study. If possible, please return the questionnaire by May 15, 2004.

Sincerely,

P. Scott Richards, Ph.D.

Professor of Counseling Psychology

(801) 422-4868

scott_richards@byu.edu 


\section{Appendix B}

Please enter the survey identification number that is on the lower right hand corner of the cover letter that was mailed to you.

ID\#

1 (a). Do you believe God may inspire scientists in their research and scholarship?
Yes
No
Uncertain

(b). Do you believe God may inspire helping professionals as they work with their clients?
Yes
No
Uncertain

2. (a). Have you ever personally felt God's inspiration in your scholarship efforts and/or scientific discovery?
Yes
No
Uncertain

(b). Have you ever personally felt God's inspiration in your professional practice?

Yes__ No___ Uncertain

3. (a) Could you please describe an occasion when you have experienced God's inspiration in your scholarship or scientific endeavors?

(b) Could you please describe an occasion when you have experienced God's inspiration in your professional practice?

4. (a) What, if anything, do you believe scientists and scholars can do to qualify for and receive inspiration from God?

(b) What, if anything, do you believe helping professionals can do to qualify for and receive inspiration from God?

5. Do you have any other thoughts about the role of inspiration in scholarship, scientific discovery, or the helping professions that you would like to share? 
Please provide the following demographic information about yourself and your education in the spaces provided below.

Male___ Female___ Age

I am: Theistic

Agnostic

Atheistic

Religious Affiliation:

How strongly religious or spiritually oriented do you consider yourself to be?

Strong Somewhat strong Not very strong Not at all

Please circle the degree that applies to you: MS PhD EdD MD MS MA LCSW BS or BA Other

What did you earn your degree in?

Where did you earn your degree?

What year did you earn your degree?

What is your professional job title (e.g., physician, psychologist, clergy, clinical social worker, etc.)?

If licensed, what type?

What is your job affiliation: University Hospital Government

Other

If applicable, please circle your academic rank: Assistant Professor Associate Professor Professor Other

If applicable what department do you work in?

How many years have you worked at this institution?

Please list other institutions you have worked for:

Please list any academic and/or scientific awards or recognitions you have received:

Thank you for participating in our survey. Would you have any interest in being interviewed to share your views in greater depth? 